University of Miami Law School

Institutional Repository

University of Miami Business Law Review

7-1-2012

\title{
Ending the Silence: Shareholder Derivative Suits and Amending the Dodd-Frank Act so "Say on Pay" Votes May be Heard in the Boardroom
}

William Alan Nelson II

Follow this and additional works at: http://repository.law.miami.edu/umblr

Part of the Business Organizations Law Commons

\section{Recommended Citation}

William Alan Nelson II, Ending the Silence: Shareholder Derivative Suits and Amending the Dodd-Frank Act so "Say on Pay" Votes May be Heard in the Boardroom, 20 U. Miami Bus. L. Rev. 149 (2012)

Available at: http://repository.law.miami.edu/umblr/vol20/iss2/3

This Article is brought to you for free and open access by Institutional Repository. It has been accepted for inclusion in University of Miami Business

Law Review by an authorized administrator of Institutional Repository. For more information, please contact library@law.miami.edu. 


\title{
ENDING THE SILENCE: SHAREHOLDER DERIVATIVE SUITS AND AMENDING THE DODD-FRANK ACT SO "SAY ON PAY" VOTES MAY BE HEARD IN THE BOARDROOM
}

\author{
WILLIAM ALAN NELSON II, ESQ. *
}

TABLE OF CONTENTS

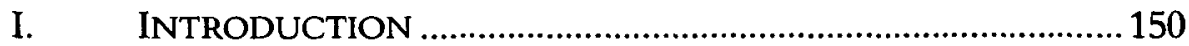

II. DODD-FRANK ACT: "SAY ON PAY" PROVISIONS .......................151

A. History of "Say on Pay" Votes ................................................... 151

B. Dodd-Frank Act Section 951 (codified at 15 U.S.C. S 78n-1) ... 154

1. Legislative History.............................................................. 154

2. Statutor Language .......................................................... 155

III. SHAREHOLDER DERIVATIVE LAWSUITS ……............................155

A. Shareholder Derivative Lawsuit Elements................................... 156

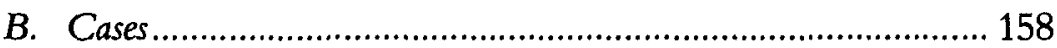

1. Witmer v. Martin ("Jacobs Engineering") ............................ 158

2. Teamsters Local 237 v. McCarthy ("Beazer Homes") .......... 160

3. Plumbers Local No. 237 v. Davis ("Umpqua Holdings") .... 162

4. Matthews v. Rynd ("Hercules Offshore")............................... 164

5. Swanson v. Weil ("Janus Capital") ....................................... 165

6. NECA-IBEW Pension Fund v. Cox ("Cincinnati Bell") ... 167

7. Haberland v. Bulkeley ("Dex One").................................... 168

C. What We Have Learned ........................................................... 170

1. Shareholders Bringing Claims Despite "Say on Pay" Votes Being Advisory ............................................................ 171

2. Companies' "Pay for Performance" Executive Compensation Structures .................................................. 172

3. Business Judgment Rule and Director Independence .............. 174

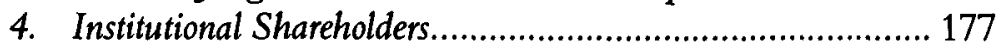

5. Executive Compensation Consultants are Not Immune

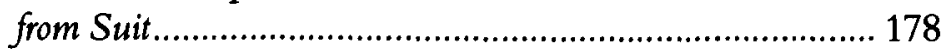

D. Court Rulings ....................................................................... 180

1. Cincinnati Bell Order ....................................................... 180

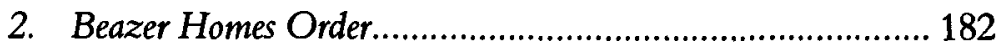

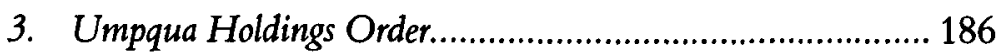

4. Comparison ….................................................................. 188

IV. SUGGESTIONS FOR COMPANIES ...........................................192

A. Re-Writing "Pay for Performance" Policies ................................. 193

B. Responding to a Negative "Say on Pay" Vote............................... 195

V. AMENDING THE DODD-FRANK ACT........................................ 197 
A. Implementing a "Two-Strikes" "Say on Pay" Re-Election Policy for Directors.

1. Language of the Proposed Amendment ................................. 197

2. Interpretation of Proposed Amendment ................................... 199

B. Cost-Benefit Analysis............................................................200

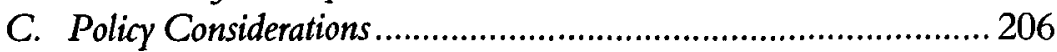

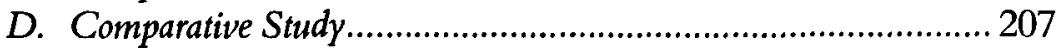

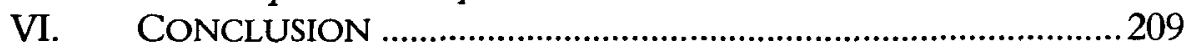

\section{INTRODUCTION}

The Dodd-Frank Wall Street Reform and Consumer Protection Act ("Dodd-Frank Act") was signed into law on July 21, 2010. ${ }^{1}$ Beginning in 2007, U.S. financial conditions deteriorated, leading to the near collapse of the U.S. financial system in September 2008. Major banks, insurers, government-sponsored enterprises, and investment banks either failed or required hundreds of billions in federal support to continue functioning. ${ }^{2}$ Congress responded to the crisis by enacting the most comprehensive financial reform legislation since the 1930s. ${ }^{3}$ The Dodd-Frank Act states its purpose is "to promote the financial stability of the United States by improving accountability and transparency in the financial system, to end 'too big to fail,' to protect the American taxpayer by ending bailouts, to protect consumers from abusive financial services practices, and for other purposes." Under Section 951 of the Dodd-Frank Act, public companies are required to conduct an "advisory" (non-binding) shareholder vote (generally known as a "say on pay" vote) at least once every three years to approve the compensation of a company's executive officers. ${ }^{5}$ Section 951 also mandates that every six years a company must ask shareholders whether the "say on pay" vote should be held every one, two, or three

* Professorial Lecturer in Law, George Washington University Law School, AttorneyAdvisor/Judıcial Law Clerk, Board of Veterans' Appeals, Department of Veterans Affairs, Managing Associate Editor, Wealth Strategies Journal, Articles Editor, Veterans Law Review, Member, Legal Writing Institute.

1 Dodd-Frank Act, Pub. L. No. 111-203, 124 Stat. 1376 (2010).

2 Baird Webel, The Dodd-Frank Wall Street Reform and Consumer Pnstection Act: Issues and Summary, Congressional Research Service (July 29, 2010).

3 Id.

4 Dodd-Frank Act, Pub. L. No. 111-203, 124 Stat. 1376 (2010).

5 Id. at $\$ 951$ (Section 951 of the Dodd-Frank Act amended the Securities Exchange Act of 1934 (Exchange Act) by adding Section 14A (codified as amended at 15 U.S.C. $\$ 78 \mathrm{n}-1$ )). 
years. ${ }^{6}$ The compensation arrangements subject to the "say on pay" vote are those set out in Item $\mathbf{4 0 2}$ of Regulation S-K, which includes all compensation paid to the Chief Executive Officer ("CEO"), Chief Financial Officer ("CFO"), and the three other highest paid executive officers. $^{7}$

The article begins by providing a history of "say on pay" votes and examining the "say on pay" provisions of the Dodd-Frank Act. The article transitions into a discussion of how the Dodd-Frank "say on pay" provisions are currently being utilized by shareholders in derivative lawsuits. Specifically, the article will analyze in detail the legal theories raised and remedies sought by the litigants and discuss, in detail, the only three post-Dodd-Frank decisions that have been handed down by courts to date. Based on this analysis, the article provides recommendations for companies on how to re-write their "pay for performance" executive compensation policies and how to respond positively and actively to a negative "say on pay" vote on executive compensation. The article concludes by proposing an amendment to the Dodd-Frank Act which, if promulgated, would provide that a second successive negative "say on pay" vote $(50 \%$ or more of shareholder votes cast against the proposed executive compensation package) on executive compensation would prompt a vote on a "spill" resolution and, if that resolution passes, all directors, except for the managing director, must stand for re-election at a special "spill" meeting within 90 days of the annual shareholder meeting where the "spill" resolution passed.

\section{DodD-Frank ACt: "Say ON PaY" Provisions}

\section{A. History of "Say on Pay" Votes}

"Say on Pay" votes are relatively new in the United States, but have been used internationally since the late 1990's. ${ }^{8}$ In July 1999, Stephen Byers, a former United Kingdom (U.K.) Secretary of State for Trade and Industry, stated that the U.K. government needed to "recognize that in a global economy world class performance must be rewarded with world

\footnotetext{
6 Id.

7 Id.

8 Paul Hodgson, $A$ Brief History of Say on Pay, GMI RatingS (Oct. 1, 2009), http://olog.thecorporatelibrary.com/blog/2009/10/a-brief-history-of-say-on-pay.html.
} 
class pay," but also that "there need[ed] to be a clear link between pay and performance."

Former Secretary Byers proposed a plan to provide shareholders with more power and play a more active role in the running of a company. ${ }^{10}$ The plan consisted of five options that he believed would give shareholders a greater role in setting executive compensation: (1) require a vote at the annual meeting on the remuneration committee's report; (2) require companies to publish a remuneration policy for approval by shareholders; (3) require annual re-election of company directors; (4) require annual election of the chairman of the remuneration committee; (5) draft new procedures which would allow shareholders to put forward resolutions on pay. ${ }^{11}$

Based in part on former Secretary Byers plan, the U.K. government enacted The Directors' Remuneration Report Regulations in 2002. ${ }^{12}$ These regulations included the requirement to put a remuneration report to a shareholder vote at each annual meeting. ${ }^{13}$ The shareholder vote, which was advisory, amounted to a "confidence vote on the work of the compensation committee, focusing in particular on executive compensation levels in light of performance and other factors." ${ }^{\text {14 }}$

Following the U.K., Australia (2004) and Spain (2007) enacted regulations requiring non-binding shareholder votes on remuneration reports. ${ }^{15}$ Countries including the Netherlands (2004), Sweden (2007), Denmark (2007), and Norway (2007) have enacted regulations requiring companies to submit remuneration reports to a binding vote. ${ }^{16}$ Under these regulations, shareholders gain greater decision-making powers. These "say on pay" regulations from different jurisdictions will be discussed in further detail later in this article. ${ }^{17}$

\footnotetext{
9 Business: The Economy Crackdown as 'Fat Cat' Pay Soars, BBC News (July 19, 1999), http://news.bbc.co.uk/2/hi/business/398040.stm.

$10 \quad$ Id.

11 Id.

12 Directors' Remuneration Report Regulations 2002 (S.I. 2002/1986) (U.K.), available at http://www.legislation.gov.uk/uksi/2002/1986/pdfs/uksi_20021986_en.pdf.

13 See id.

14 Jeffrey N. Gordon, Executive Compensation: If There's $A$ Problem, What's the Remedy? The Case for "Compensation Discussion and Analysis," 30 J. CORP. L. 675, 699 (2005).

15 Michel Magnan and Claudine Mangen, "Is Say on Pay an Effective Govenance Tool?" Report submitted to the Institute for the Governance of Public and Private Organizations.

16 Id

17 See infra Section V(D).
} 
As noted above, "say on pay" votes in the United States are relatively new. Escala Group, a global collectibles company, issued a proxy statement in October 2005, stating that the company would put executive compensation packages up for a shareholder vote. ${ }^{18}$ Congress has also tried to pass legislation mandating "say on pay" votes on executive compensation. In November 2005, Representative Barney Frank introduced a bill that would require Congress to amend the Securities Exchange Act of 1934 ("Exchange Act") to require additional disclosure to shareholders of executive compensation. ${ }^{19}$ It would also require a separate shareholder vote to approve an executive compensation plan; however, it did not state whether the vote would be binding on a company and its board of directors..$^{20}$ In May 2009, Senator Charles Schumer introduced a bill to provide shareholders with enhanced authority over the nomination, election, and compensation of public company executives. ${ }^{21}$ It would also require a separate shareholder vote to approve an executive compensation plan, but stated that the vote would be non-binding and would not affect the fiduciary duties of a company or its board of directors..$^{22}$ In July 2009, Representative Barney Frank introduced a bill to amend the Exchange Act to provide shareholders with a non-binding vote on executive compensation and to prevent perverse incentives in the compensation practices of financial institutions. ${ }^{23}$ None of these bills were enacted into law.

In July 2009, President Obama signed into law the American Recovery and Reinvestment Act of 2009. ${ }^{24}$ The Recovery Act amended Section 111(e) of the Emergency Economic Stabilization Act of $2008^{25}$ to require "say on pay" votes for companies who received aid from the United States government under the Troubled Asset Relief Program (TARP) ${ }^{26}$

See Hodgson, supra note 8; see also, EsCAla Group, 2005 Proxy STATEMENT (2005) (The company issued a statement noting that the board would put both the outgoing CEO's and the incoming CEO's compensation packages up for a shareholder vote).

19 See Protection Against Executive Compensation Abuse Act of 2005, H.R. 4291, 109th Cong. (1st Sess. 2005).

$20 \quad$ Id.

21 See Shareholder Bill of Rights Act of 2009, S. 1074, 111th Cong. (1st Sess. 2009).

22 Id.

23 See Corporate and Financial Institution Compensation Fairness Act of 2009, H.R. 3269, 111th Cong. (1st Sess. 2009).

24 Recovery Act, Pub. L. No. 111-5, 123 Stat. 115 (2009).

25 Economic Stabilization Act, Pub. L. No. 110-343, 122 Stat. 3765 (2008).

26 Recovery Act, Pub. L. No. 111-5, 123 Stat. 115 (2009). 
B. Dodd-Frank Act Section 951 (codified at 15 U.S.C. \$ 78n-1)

\section{Legislative History}

The proposals for a "say on pay" vote on executive compensation were initially set forth by the Obama Administration in June 2009 via the Department of Treasury's "White Paper" on financial reform. ${ }^{27}$ The Administration recognized the need for "say on pay" rules, which would require shareholder votes on executive compensation packages. While such votes would be non-binding, they would provide "a strong message to management and boards and serve to support a culture of performance, transparency, and accountability in executive compensation." 28 The Administration believed that legislation authorizing "say on pay" rules for all public companies could "help restore investor trust by promoting increased shareholder participation and increasing accountability of board members and corporate management." 29 It would provide shareholders of all public U.S. companies with the same rights that are accorded to shareholders in many other countries. ${ }^{30}$ Legislators also stated that "say on pay" votes on executive compensation "serve as a direct referendum on the decisions of the compensation committee and offer a more targeted way to signal shareowner discontent than withholding votes from committee members." 31

The Dodd-Frank Act was initially proposed in Congress on December 2, 2009, in the House of Representatives by Representative Barney Frank, and in the Senate by Senator Chris Dodd. ${ }^{32}$ The original language of the Dodd-Frank Act provided for a shareholder vote that would not be binding on a company or its board of directors. The vote would also not be construed as overruling a decision by the board or create or imply any additional fiduciary duties on the board. ${ }^{33}$ There was virtually no change in the language of the introduced bill and the final bill that was enacted into law. ${ }^{34}$

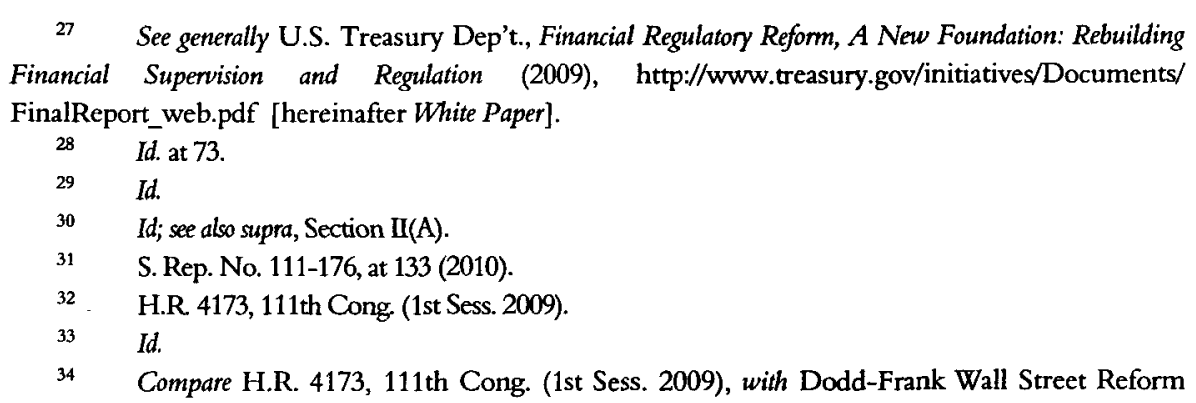




\section{Statutory Language}

Section 951 of the Dodd-Frank Act expanded "say on pay" to all public companies by adding a new Section 14(a) to the Exchange Act. ${ }^{35}$ The statutory language provides: "[at least] once every 3 years, a proxy or consent or authorization for an annual or other meeting of the shareholders for which the proxy solicitation rules of the Commission require compensation disclosure shall include a separate resolution subject to shareholder vote to approve the compensation of executives." ${ }^{36}$ The statutory language also provides that: "[at least] once every 6 years, a proxy or consent or authorization for an annual or other meeting of the shareholders for which the proxy solicitation rules of the [SEC] require compensation disclosure shall include a separate resolution subject to shareholder vote to determine whether ["say on pay"] votes ... will occur every 1,2 , or 3 years. ${ }^{37}$

The Dodd-Frank Act makes clear that the "say on pay" votes are merely advisory and are not binding a company's board of directors. ${ }^{38}$ The "say on pay" vote may not be construed as overruling a decision by a company or its board of directors. It cannot change or add to the fiduciary duties of a company's board of directors and it may not restrict or limit the ability of shareholders to make proposals for inclusion in proxy materials related to executive compensation. ${ }^{39}$

\section{SHAREHOLDER DERIVATIVE LAwSUITS}

Nearly 2,300 companies held "say on pay" votes in $2011 .^{40}$ Shareholders only returned negative "say on pay" votes at 45 , or $1.9 \%$, of these companies. ${ }^{41}$ In a majority of the negative "say on pay" votes, less

and Consumer Protection Act, Pub. L. No. 111-203, 124 Stat. 1376, 1899.

35 Dodd-Frank Act, Pub. L. No. 111-203, \$951, 124 Stat. 1376 (2010).

3615 U.S.CA $\$ 78 n-1$ (a)(1) (West 2002 \& Supp. 2011).

$37 \quad$ Id. at $\$ 78 \mathrm{n}-1(\mathrm{a})(2)$.

$38 \quad$ Id. at $\$ 78 \mathrm{n}-1(\mathrm{c})$.

39 Id.

40 Dechert LLP, Defending Against Shareholder 'Say on Pay' Suits, MONDAQ, (Sept. 13, 2011), http://www.mondaq.com/unitedstates/x/145050/Corporate +Crime/Defending + Against + Shareholder +SayOnPay+Suits; see also List: Companies Failing to Obtain Majority Vote on Pay Packages, COMPENSATIONSTANDARDS.COM, http://www.compensationstandards.com/Member/Areas/ Advisory.htm\#6 (last visited Dec. 20, 2011).

41 Michael R. Lettenberg, et al, The Votes Are In - Deconstructing the 2011 Say on Pay Vote, SCHULTE ROTH \& ZABEL, (June 17, 2011), http://www.srz.com/files/News/dbfOba31-2627-402cb211-3a6cc3e83295/Presentation/NewsAttachment/643250b0-a583-444c-9011- 
than $45 \%$ of the shareholders voted in favor of the company's executive compensation package. ${ }^{42}$ Shareholder derivative lawsuits have been commenced against the board of directors, certain executive officers, and executive compensation consultants at 7 of the companies that received negative "say on pay" votes. ${ }^{43}$

The allegations in the Complaints generally claim that the directors breached their fiduciary duties by approving executive compensation packages that shareholders deemed unreasonable and excessive. The breaches include allegations that "directors diverted corporate assets to the executives in a manner that put the executives' interests ahead of those of the shareholders" and "that the companies that have adopted 'pay-forperformance' compensation policies failed to disclose in their proxy statements that the compensation awards were made notwithstanding or in contravention to the policies." ${ }^{44}$ Finally, the complaints also bring claims for corporate waste based on the alleged excessive size of the executive compensation awards. ${ }^{45}$

\section{A. Shareholder Derivative Lawsuit Elements}

A shareholder's derivative action is an action brought by one or more shareholders of a corporation to enforce a corporate right or to prevent or

05277889fc1e/062811_The_Votes_Are_In_Deconstructing_the_2011_Say_on_Pay_Vote.pdf; see also Voting Analytics: An Analysis of Voting Results and Performance at Russell 3000 Companies, EQUILAR (July 2011), http://www.equilar.com/knowledge-network/research-articles/2011/201107-voting-analytics. php [hereinafter Equilar Report].

42 Pamela B. Greene, et al., Lessons Leamed from Initial 'Say-on-Pay' Litigation: Plaintiffs' Attomeys Start Utilizing "No" Votes as a Basis for Claims Against Directors, MARTINDALE.COM, (July 25, 2011), http://www.martindale.com/litigation-law/article_Mintz-Levin-Cohn-Ferris-Glovsky-Popeo-

PC_1316956.htm; see also Ed Hauder, SOP Votes With Less Than 50\% Support/Not Approved as of November 14, 2011, SAY ON PAY (Mar.15, 2011, 11:54 PM), http://say-on-pay.com/say-on-payfrequency-tracking/.

43 The companies include Jacobs Engineering Group, Inc.; Beazer Homes USA, Inc.; Umpqua Holdings Corp.; Hercules Offshore, Inc.; Janus Capital Group, Inc.; Cincinnati Bell, Inc.; and Dex One Corp. See, e.g., Witmer v. Martin, et al., BC454543 (Cal. Super. Ct., Los Angeles Cty., Feb. 4, 2011) [hereinafter Jacobs Engineering]; Teamsters Local 237 v. McCarthy, et al., 2011 CV 197841 (Ga. Super. Ct., Fulton Cty., March 15, 2011) [hereinafter Beazer Homes]; Plumbers Local No. 237 v. Davis, et al., 11-cv-633 (D. Ore., May 25, 2011) [hereinafter Umpqua Holdings]; Matthews v. Rynd, et al, 201134508 (Tex. Dist. Ct., Harris Cty., June 8, 2011) [hereinafter Hercules Offshore]; Swanson v. Weil, et al., 11-cv-02142 (D. Col., August 16, 2011) [hereinafter Janus Capital]; NECAIBEW Pension Fund v. Cox, et al., 11-cv-451 (S.D. Ohio, July 5, 2011) [hereinafter Cincinnati Bell]; Haberland v. Bulkeley, 5:11cv-00463-D (E.D.N.C, Sept. 1, 2011) [hereinafter Dex One].

44 Greene, supra note 42.

45 Id. 
remedy a wrong to the corporation. ${ }^{46}$ In a derivative action, "the corporation is the real party in interest, and any recovery goes to the corporation, rather than to the shareholder who brings the action.. ${ }^{47}$ The right of a shareholder to bring a derivative lawsuit "is not a property right or a vested right and is not beyond the control of the courts or the legislature; a state has plenary power over stockholders' derivative actions. ${ }^{\text {n8 }}$

Shareholder derivative lawsuits generally allege that the company's directors or officers violated one or more fiduciary duties owed to the company and its shareholders. ${ }^{49}$ Typically, plaintiffs don't seek to extract monetary damages, but rather they seek to protect their long-term interest in the company by imposing corporate governance and management changes. ${ }^{50}$ There are generally two broad categories of breach of fiduciary duty that underlie derivative actions: duty of loyalty and duty of care. ${ }^{51}$

Shareholders suing derivatively must make demand upon the corporation's directors to take corrective action, or else state with particularity the reasons why demand would be futile, before they may proceed with the action..$^{52}$ Even when shareholder derivative claims are brought under federal law, the substantive law of the state of incorporation is applied to determine if the failure of the plaintiff to make a demand is excused. ${ }^{53}$ "A demand on the corporate directors, officers, or managers to bring suit and their wrongful refusal to do so is necessary before a stockholder may maintain a suit on behalf of the corporation, in

4619 AM. JUR. 2D Copporations $\$ 1944$ (2011); see also Koster v. Lumbermens Mut Casualty Co, 330 U.S. 518, 522 (1947) ("The cause of action which [a plaintiff in shareholders' derivative action] brings before the court is not his own but the corporation's. It is the real party in interest and [the shareholder] is allowed to act in protection of its interest somewhat as a "next friend" might do for an individual, because it is disabled from protecting itself.").

47 Id.

4819 AM. JUR. 2D Corporations $\$ 1959$ (2011); see also Cohen v. Benefit Indus. Loan Corp., 337 U.S. 541,549 (1949) (“ $[\mathrm{t}]$ he very nature of the stockholder's derivative action makes it one in the regulation of which the legislature of a state has wide powers.").

49 See Dave Bradford, Shareholder Derivative Suits: A Growing Concem for Copporate Dinectors and Officers, CNAPRO (June 2005), http//www.cnapro.com/pdf/ShareholderDeriviativeSuits_Advisen.pdf.

$50 \quad$ Id.

51 Id.

52 FED. R. CIV. P. 23.1(b)(3) (the plaintiffs must “(3) state with particularity: (A) any effort by the plaintiff to obtain the desired action from the directors or comparable authority and, if necessary, from the shareholders or members; and $(B)$ the reasons for not obtaining the action or not making the effort.").

53 See Kamen v. Kemper Fin. Serv. Inc., 500 U.S. 90, 98 (1991); see also United States v. Kimbell Foods, Inc., 440 U.S. 715, 728 (1979). 
the absence of circumstances excusing the demand." ${ }^{54}$ The demand must be made before the filing of the action. ${ }^{55}$ The purpose of the "demand" rule is "to give the derivative corporation itself the opportunity to take over a suit which was brought on its behalf in the first place, and thus to allow the directors the chance to occupy their normal status as conductors of the corporation's affairs." ${ }^{56}$

The demand requirement for maintaining derivative actions is also not a mere formality; it is an important aspect of corporate law that limits the powers of individual shareholders and directors to control corporate litigation. ${ }^{57}$ Demand is excused in situations where the complaint raises "a reasonable doubt as to (i) director disinterest or independence or (ii) whether the directors exercised proper business judgment in approving the challenged transaction." ${ }^{.58}$ Demand futility must be determined at the time the shareholder derivative lawsuit is filed. ${ }^{59}$ The application of these shareholder derivative lawsuit elements will be discussed in further detail later in this article. ${ }^{60}$

\section{B. Cases}

\section{Witmer v. Martin ("Jacobs Engineering")}

In the Jacobs Engineering case, a shareholder derivative action was brought by shareholders on behalf of Jacobs Engineering Group Inc. ("Jacobs Engineering") against Jacobs Engineering's Board of Directors ("Jacobs Board"), certain Jacobs Engineering senior officers, and Jacobs Engineering's executive compensation consultant, Frederic W. Cook \& Co., Inc. (FWC). ${ }^{61}$ The Complaint seeks to hold defendants liable for

\footnotetext{
54 19 AM. JUR. 2D Corporations $\$ 1961$ (2011).

$55 \quad$ Id.

56 Brody v. Chemical Bank, 517 F.2d 932, 934 (2d Cir. 1975); see also Mills v. Esmark, Inc, 91 F.R.D. 70,72 (N.D.Ill. 1981) (the purpose of demand requirement is to allow a corporation to activate intercorporate remedies to address shareholder complaints pror to resorting to judicial intervention).

57 See FED. R. CIV. P. 23.1(b)(3).

58 RCM Securities Fund, Inc. v. Stanton, 928 F.2d 1318, 1330 (2d Cir. 1991) (quoting Aronson v. Lewis, 473 A.2d 805, 814 (Del. 1984)) (applying Delaware law); see also Grobow v. Perot, 539 A.2d 180, 188-89 (Del..1988) ("The test is disjunctive; demand is excused when the complaint alleges facts that raise a reasonable doubt as to either director independence or the exercise of proper business judgment.").

59 Stepak v. Dean, 434 A.2d 388, 390 (Del. Ch. 1981); Cramer v. Gen. Tel. \& Elec. Corp., 582 F.2d 259, 276 (3d Cir. 1978).

60 See infra Sections III (C) \& (D).

61 Complaint at I 1, Witmer v. Martin, No. BC454543 (Cal. Super. Ct., Los Angeles Cty filed
} 
"breach of [] fiduciary duties of candor, good faith and loyalty, and for corporate waste, unjust enrichment, aiding and abetting, and breach of contract in connection with the award of excessive and unwarranted 2010 executive compensation." ${ }^{22}$ The plaintiffs also allege that Jacobs Engineering's earnings and revenue performance in 2010 was "abysmal;" however, the Jacobs Board still authorized pay increases for the company's senior officers in $2010 .{ }^{63}$ In the factual allegations section, the plaintiffs state that in 2010, Jacobs Engineering's revenues decreased by $\$ 1.5$ billion dollars $(14 \%)$, net earnings decreased $\$ 153$ million dollars $(38.5 \%)$, and earnings per share decreased $\$ 1.28$ dollars per share $(39.3 \%) .{ }^{64}$ The plaintiffs claim that even though most of the key financial metrics declined in 2010, executive compensation still increased.

The plaintiffs discuss how Jacobs Engineering's executive compensation practices are rooted in a "pay for performance" policy. ${ }^{65}$ In the 2011 Proxy Statement, the Jacobs Board represented that the Board's philosophy was 'to provide a strong link between pay and Company performance." "[was] to establish executive compensation programs that reward superior performance [and] have consequences for underperformance." ${ }^{37}$

In Jacobs Engineering's 2011 Proxy Statement, the Jacobs Board advised shareholders to approve the executive compensation package for $2010 .^{68}$ In January 2011, a majority of shareholders rejected Jacobs Engineering's executive compensation package for $2010 .{ }^{69}$ Even with the negative vote by the shareholders on executive compensation, the Jacobs Board did not alter or amend the 2010 executive compensation structure. $^{70}$

The plaintiffs allege that a pre-suit demand upon the Jacobs Board is a "useless and futile" action, and therefore, excused for several reasons. ${ }^{71}$

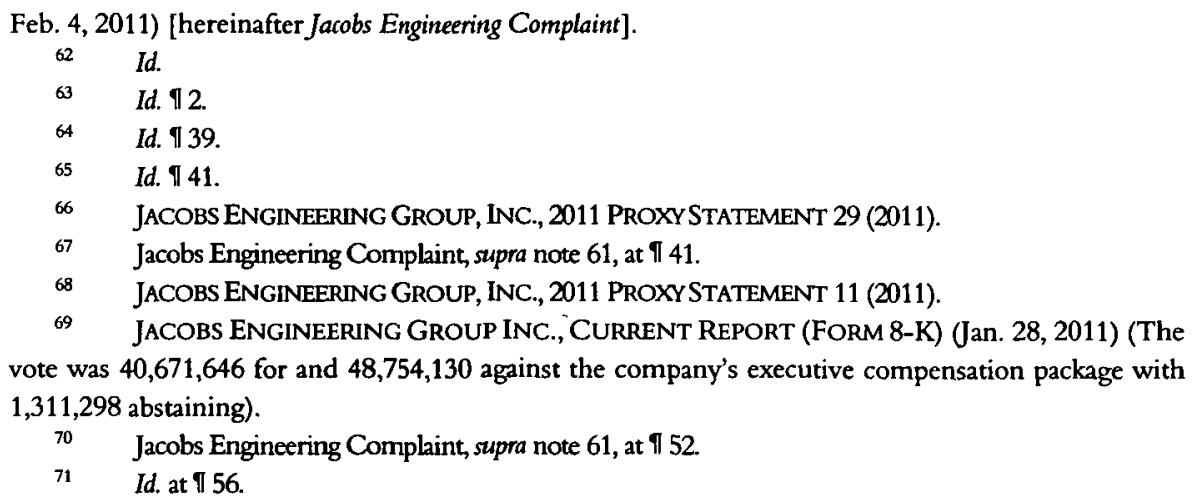


The plaintiffs claim that a pre-suit demand is unnecessary because the Jacobs Board recommended to shareholders to approve the 2010 executive compensation package and also failed to take any action once the recommendation was rejected; therefore, the plaintiffs allege that the Jacobs Board has demonstrated hostility to the derivative action and demand would be a useless and futile act. ${ }^{72}$ The plaintiffs also claim that demand is excused in regard to director Craig L. Martin, because he serves as President and CEO of Jacobs Engineering; therefore, he received the unwarranted executive compensation and lacks independence. ${ }^{73}$

The Complaint lists five causes of action. The first cause of action is for breach of fiduciary duty. The shareholders allege that the defendants breached their fiduciary duties of loyalty and good faith by failing to disclose material information and/or made misrepresentations to shareholders regarding Jacobs Engineering's 2010 executive compensation structure. ${ }^{74}$ The second cause of action is against FWC for aiding and abetting breaches of fiduciary duties. The Complaint alleges that FWC "substantially assist[ed] the commission of the wrongdoing" perpetrated by the Jacobs Board. ${ }^{75}$ The third cause of action is against FWC for breach of contract. The Complaint alleges that FWC breached its contract with Jacobs Engineering by advising the Board to increase executive compensation for $2010 .^{76}$ The fourth cause of action is for corporate waste. The Complaint alleges that the Board "[gave] away millions of dollars via a clandestine executive compensation scheme." The fifth cause of action is for unjust enrichment. The Complaint alleges that the senior officers of the company have been unjustly enriched in "the form of unjustified salaries, benefits, bonuses, [and] stock option grants."

\section{Teamsters Local 237 v. McCarthy ("Beazer Homes")}

In the Beazer Homes case, a shareholder derivative action was brought by shareholders on behalf of Beazer Homes USA, Inc. ("Beazer Homes") against Beazer Homes' Board of Directors ("Beazer Board"), certain Beazer Homes senior officers, and Beazer Homes' executive

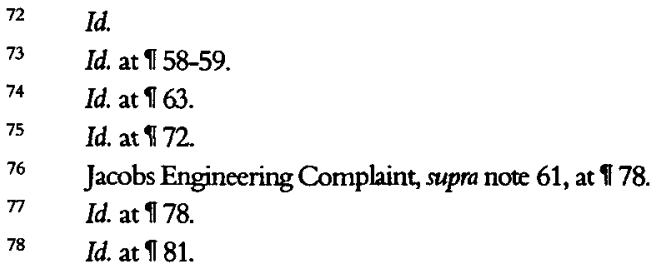


compensation consultants, PricewaterhouseCoopers LLC ("PwC") and MarksonHRC, LLC ("Markson"). ${ }^{79}$ The Complaint alleges that the Beazer Board's decision to "increase CEO and top executive pay in 2010, despite [Beazer Homes'] massive $\$ 34$ million net loss, w[as] disloyal, unreasonable, and not the product of a valid exercise of business judgment. ${ }^{n 00}$ The Complaint also alleges that the defendants violated Beazer Homes' "pay-for-performance" policy ${ }^{81}$ In the Complaint, the plaintiffs state that in 2010, Beazer Homes' had a total net loss of $\$ 34$ million dollars, and earnings per share decreased $\$ 0.57$ dollars per share $(17.23 \%){ }^{82}$ The plaintiffs claim that even though earnings and share prices fell, executive compensation was increased by almost $8 \% .{ }^{83}$

The plaintiffs discuss how Beazer Homes' executive compensation practices are rooted in a "pay for performance" policy. ${ }^{84}$ In the 2011 Proxy Statement, the Beazer Board represented that "Our core compensation objective continues to be that we will pay for performance - we believe we should pay higher compensation when our management team achieves the predetermined goals and lower compensation when it does not. ${ }^{85}$ The Proxy Statement also states that Beazer Homes' "compensation programs are premised on the achievement of [] financial [] goals [] that the Compensation Committee and the Board of Directors believe are critical to enhancing stockholder value. ${ }^{n 86}$ The Beazer Board advised shareholders to approve the executive compensation package for $2010{ }^{87}$ In January 2011, a majority of shareholders rejected Beazer Homes' executive compensation package for $2010 .^{88}$

The plaintiffs allege that a pre-suit demand upon the Beazer Board is a "useless and futile action." ${ }^{\text {" Th }}$ The plaintiffs argue that the demand requirement is excused, because the Beazer Board is interested in the outcome of the litigation and also because they recommended that the

79 Complaint, Teamsters Local 237 v. McCarthy, 2011 CV 197841 (Ga. Super. Ct., Fulton Cty, filed Mar. 15, 2011) [hereinafter Beazer Homes Complaint].

80 Id. at I 3.

81 Id.

82 Id. at $\uparrow 2$.

83 Id.

84 Id. at $\uparrow 27$.

85 BEAZER HOMES USA, INC., 2011 PROXYSTATEMENT 31 (2010)

$86 \quad$ Id.

87 Id. at $16-17$.

88 BEAZER HOMES USA, INC., CURRENT REPORT (FORM 8-K) (Feb. 2, 2011) (The vote was $20,172,993$ for and $23,632,597$ against the company's executive compensation package with 142,674 abstaining).

89 Beazer Homes Complaint, supra note 79, at 142 . 
Beazer Homes' shareholders approve the 2010 executive compensation package. ${ }^{90}$

The Complaint lists four causes of action. The first cause of action is for breach of fiduciary duty. The shareholders allege that the defendants breached their fiduciary duty of loyalty by approving the 2010 executive compensation package and by omitting material facts from the shareholders regarding the 2010 executive compensation package. ${ }^{91}$ The second cause of action is against PwC and Markson for aiding and abetting breaches of fiduciary duties. The third cause of action is against PwC and Markson for breach of contract. The Complaint alleges that PwC and Markson breached their contracts with Beazer Homes by advising the Beazer Board to increase executive compensation for $2010 .^{92}$ The fourth cause of action is for unjust enrichment. The Complaint alleges that the senior officers of the company have been unjustly enriched because "[t]he 2010 pay hikes for Beazer's CEO and top executives ... were unwarranted in light of Beazer's dismal 2010 financial performance. ${ }^{93}$

\section{Plumbers Local No. 237 v. Davis ("Umpqua Holdings")}

In the Umpqua Holdings case, a shareholder derivative action was brought by shareholders on behalf of Umpqua Holding Corp. ("Umpqua Holdings") against Umpqua Holdings' Board of Directors ("Umpqua Board"), certain Umpqua Holdings senior officers, and Umpqua Holdings' executive compensation consultants, $\mathrm{PwC}^{94}$ The Complaint alleges that the Umpqua Board's decision to "increase [executive compensation] in 2010, despite [Umpqua Holdings'] severely impaired financial results, were disloyal, irrational and unreasonable." ${ }^{.95}$

In the Complaint, the plaintiffs state that in 2010, Umpqua Holdings' annual shareholder return declined to negative $7.7 \% .{ }^{96}$ The plaintiffs claim that even though annual shareholder return declined, executive compensation was increased, on average, $118.8 \%{ }^{97}$ The plaintiffs discuss

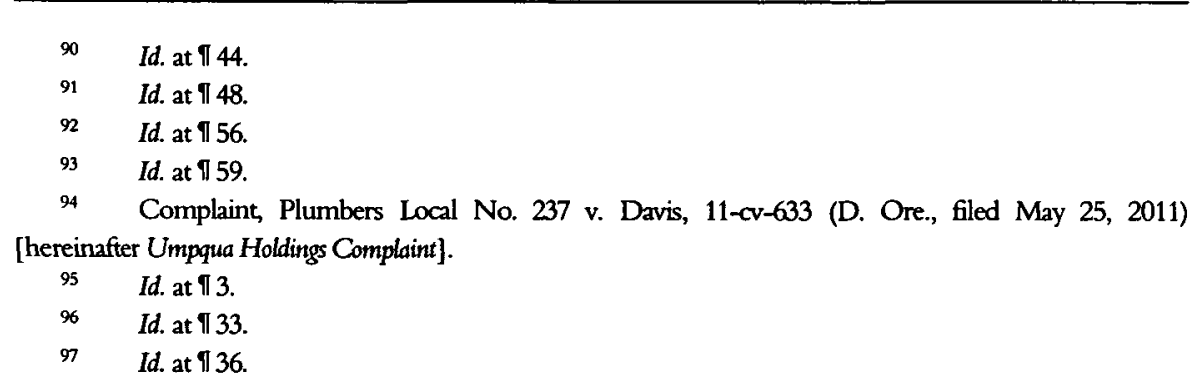


how Umpqua Holding's executive compensation practices are rooted in a "pay for performance" policy. ${ }^{98}$ In the 2011 Proxy Statement, the Umpqua Board represented that "Umpqua's executive compensation is designed to recognize superior operating performance ... Our executive compensation philosophy is simple: we pay competitive base salaries and we strongly reward performance." Umpqua Holdings "Strongly link[s] the interests of executives to the value derived by our shareholders from owning Company stock." 100 The Umpqua Board advised shareholders to approve the executive compensation package for 2010. ${ }^{101}$ In April 2011, a majority of shareholders rejected Umpqua Holdings' executive compensation package for $2010 .^{102}$

The plaintiffs allege that a pre-suit demand upon the Umpqua Board is a "useless and futile action." requirement is excused, because the Umpqua Board was "interested" in the outcome of the action and by recommending that shareholders approve the 2010 executive compensation, the Umpqua Board demonstrated its hostility towards the derivative action..$^{104}$

The Complaint lists four causes of action. The first cause of action is for breach of fiduciary duty. The shareholders allege that the defendants breached their fiduciary duty of loyalty by approving the 2010 executive compensation package and by omitting material facts from the shareholders regarding the 2010 executive compensation package. ${ }^{105}$ The second cause of action is against PwC for aiding and abetting breaches of fiduciary duties. The third cause of action is against PwC for breach of contract. The Complaint alleges that $\mathrm{PwC}$ breached their contracts with Umpqua Holdings by advising the Umpqua Board to increase executive compensation for 2010. ${ }^{106}$ The fourth cause of action is for unjust enrichment. The Complaint alleges that the senior officers of the company have been unjustly enriched because " $[t]$ he 2010 pay hikes for

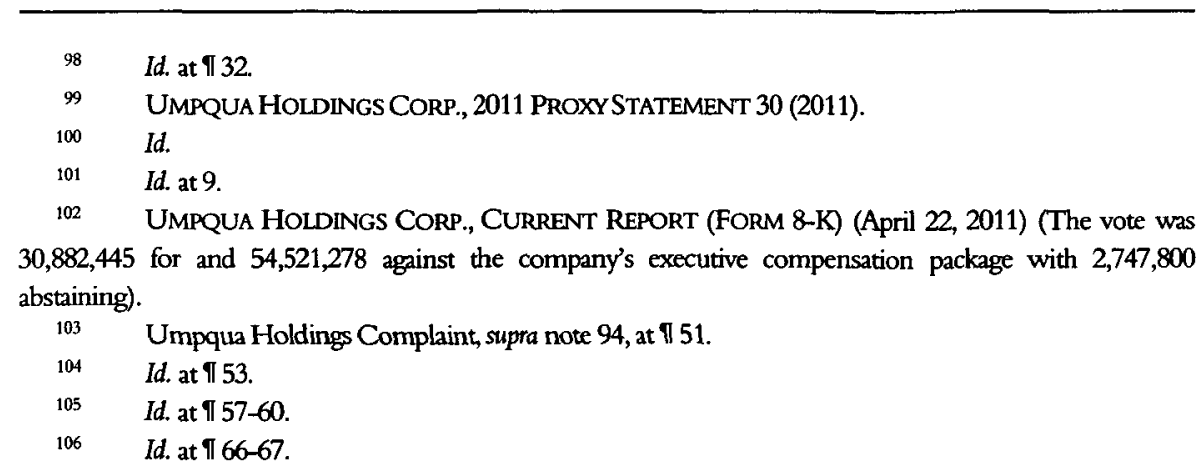


Umpqua's CEO and top executives violated Umpqua's pay-forperformance policy, and were unwarranted in light of Umpqua's dismal 2010 financial performance."107

\section{Matthews v. Rynd ("Hercules Offshore")}

In the Hercules Offshore case, a shareholder derivative action was brought by shareholders on behalf of Hercules Offshore, Inc. ("Hercules Offshore") against Hercules Offshore's Board of Directors ("Hercules Board"), certain Hercules Offshore senior officers, and Hercules Offshore's executive compensation consultant, FWC. ${ }^{108}$ The Complaint alleges that the Hercules Board's decision to "increase [executive compensation] in 2010, despite [Hercules Offshore's] severely impaired financial results, was disloyal, irrational and unreasonable." 109

In the Complaint, the plaintiffs state that in 2010, Hercules Offshore suffered a net operating loss of $\$ 145,160,000$ dollars and saw annual shareholder return decline $27.2 \% .{ }^{110}$ The plaintiffs claim that even though the company suffered a net operating loss and annual shareholder return declined, executive compensation was increased, on average $122.9 \% .{ }^{111}$ The plaintiffs discuss how Hercules Offshore's executive compensation practices are historically rooted in a "pay for performance" policy. ${ }^{112}$ In the 2011 Proxy Statement, the Hercules Board represented that the executive compensation program is designed "to attract, retain, motivate, and reward executive officers who are capable of leading [Hercules Offshore] in a complex, competitive, and changing industry."113 The Proxy Statement also states that the Hercules Board has a policy to "pay for performance."114 The Hercules Board advised shareholders to approve the executive compensation package for $2010 .{ }^{115}$ In May 2011, a majority of shareholders rejected Hercules Offshore's executive compensation package for $2010 .^{116}$

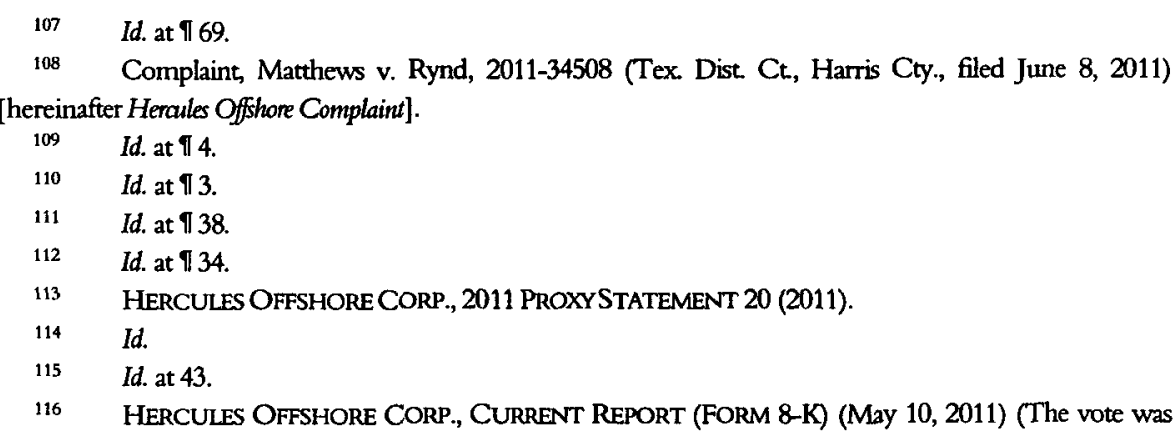


The plaintiffs allege that a pre-suit demand upon the Hercules Board is a "useless and futile action." 117 The plaintiffs argue that the demand requirement is excused, because the Hercules Board was "interested" in the outcome of the action and that by recommending that shareholders approve the 2010 executive compensation, the Hercules Board demonstrated its hostility towards the derivative action. ${ }^{118}$ The plaintiffs also argue that the Hercules Board is not entitled to business judgment protection. ${ }^{119}$

The Complaint lists four causes of action. The first cause of action is for breach of fiduciary duty. The shareholders allege that the defendants breached their fiduciary duty of loyalty by approving the 2010 executive compensation package and by violating the company's own "pay for performance" policy regarding executive compensation. ${ }^{120}$ The second cause of action is against FWC for aiding and abetting breaches of fiduciary duties. The third cause of action is against FWC for breach of contract. The Complaint alleges that FWC breached its contracts with Hercules Offshore by advising the Hercules Board to increase executive compensation for 2010. ${ }^{121}$ The fourth cause of action is for unjust enrichment. The Complaint alleges that the senior officers of the company have been unjustly enriched because " $t$ t]he 2010 pay hikes for Hercules Offshore's CEO and top executives violated Hercules Offshore's pay-for-performance policy, and were unwarranted in light of Hercules Offshore's dismal 2010 financial performance."122

\section{Swanson v. Weil ("Janus Capital")}

In the Janus Capital case, a shareholder derivative action was brought by shareholders on behalf of Janus Capital Group, Inc. ("Janus Capital") against Janus Capital's Board of Directors (Janus Board) and certain Janus Capital senior officers. ${ }^{123}$ The Complaint seeks relief for "Janus Board's disloyalty, its CEO and top executives' unjust enrichment, and its

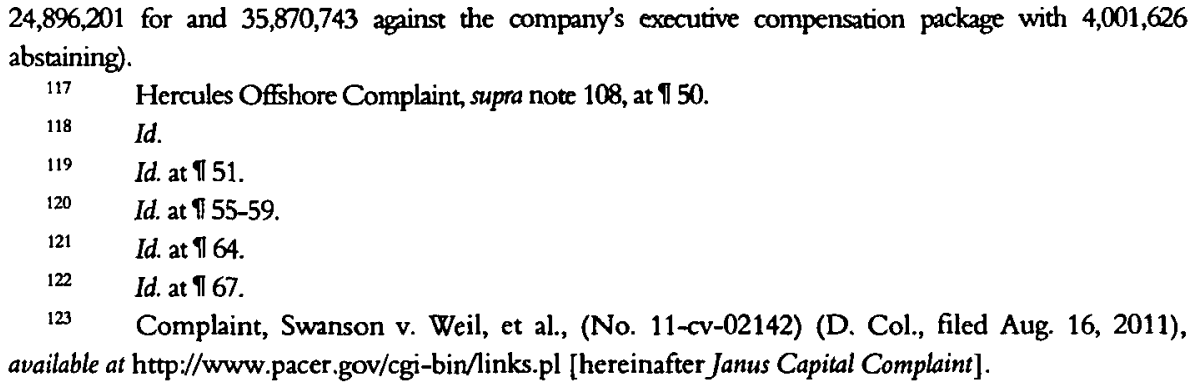

$24,896,201$ for and 35,870,743 against the company's executive compensation package with 4,001,626 abstaining).

117 Hercules Offshore Complaint, supra note 108, at II 50.

$118 \quad$ Id.

119 Id. at 151.

120 Id. at $\$ 55-59$.

121 Id. at 164.

122 Id. at 167

123 Complaint, Swanson v. Weil, et al., (No. 11-cv-02142) (D. Col., filed Aug. 16, 2011), available at http://www.pacer.gov/cgi-bin/links.pl [hereinafter Janus Capital Complaint]. 
compensation consultant's aiding and abetting breaches of fiduciary duty and breach of contract." ${ }^{24}$ The Complaint also alleges "the false and misleading Proxy Statement [] tainted the stockholder vote for the directors in violation of Section 14 of the Exchange Act." ${ }^{25}$

In the Complaint, the plaintiffs state that in 2010 Janus Capital stock price suffered a $4.7 \%$ decrease. ${ }^{126}$ The plaintiffs claim that even though the company suffered a decrease in stock price, executive compensation was increased. ${ }^{127}$ The plaintiffs also cite to a New York Times article that criticized Janus Capital's executive compensation policies. ${ }^{128}$ The plaintiffs discuss how Janus Capital's executive compensation practices are historically rooted in a "pay for performance" policy. ${ }^{129}$ In the 2011 Proxy Statement, the Janus Board represented that "we design our executive officer compensation programs to provide variable compensation opportunities to our key executives that reflect both Company performance and individual executive performance, along with the alignment of that compensation with the interests of public and fund shareholders." 130 The Janus Board advised shareholders to approve the executive compensation package for 2010. ${ }^{131}$ In May 2011, a majority of shareholders rejected Janus Capital's executive compensation package for $2010 .{ }^{132}$

The plaintiffs allege that a pre-suit demand upon the Janus Board is a "useless and futile action." requirement is excused, because the Janus Board was "interested" in the outcome of the action and that the Janus Board made false and misleading statements in Janus Capital's 2011 Proxy Statement relating to the company's "pay-for-performance" policy. ${ }^{134}$ The plaintiffs also argue that the Janus Board is not entitled to business judgment protection. ${ }^{135}$

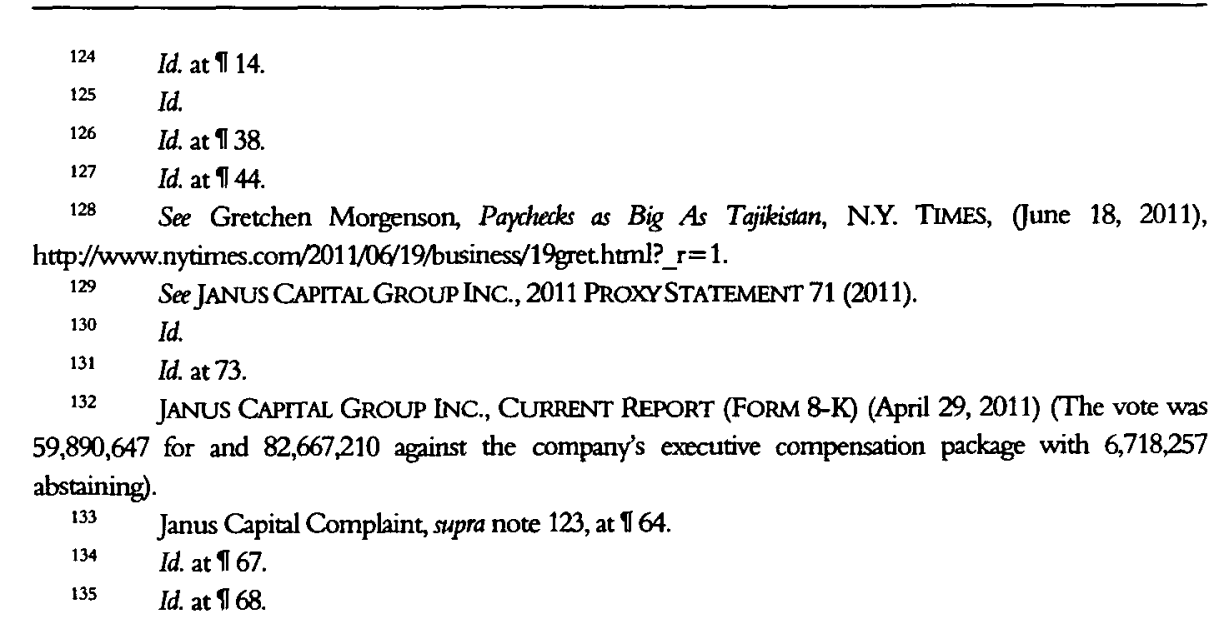


The Complaint lists three causes of action. The first cause of action is for violation of Section 14(a) of the Exchange Act. The shareholders allege that the defendants made false and misleading statements concerning the company's policy regarding "pay for performance" executive compensation. ${ }^{136}$ The second cause of action is for breach of fiduciary duty. The shareholders allege that the defendants breached their fiduciary duty of loyalty by approving the 2010 executive compensation package and by violating the company's own policy regarding "pay for performance" executive compensation. The third cause of action is for unjust enrichment. The Complaint alleges that the senior officers of the company have been unjustly enriched because "payments to Janus' CEO and top executives violated Janus' pay-for-performance policy, and were unwarranted and undeserved in light of Janus' dismal 2010 financial performance." ${ }^{137}$

\section{NECA-IBEW Pension Fund v. Cox ("Cincinnati Bell")}

In the Cincinnati Bell case, a shareholder derivative action was brought by shareholders on behalf of Cincinnati Bell, Inc. ("Cincinnati Bell") against Cincinnati Bell's Board of Directors ("Cincinnati Board") certain Cincinnati Bell senior officers, and Cincinnati Bell's executive compensation consultant, Towers Watson \& Co. ("TWC"). ${ }^{138}$ The Complaint alleges the "Board's decisions to increase CEO and top executive pay in 2010, despite the Company's severely impaired financial results, were disloyal, irrational and unreasonable, and not the product of a valid exercise of business judgment."139

In the Complaint, the plaintiffs state that in 2010, Cincinnati Bell suffered a $\$ 61.3$ million dollar decline in net income and negative $18.8 \%$ annual shareholder return. ${ }^{140}$ The plaintiffs claim that even though the company suffered a decrease in net income, executive compensation was increased. ${ }^{141}$ The plaintiffs discuss how Cincinnati Bell's executive compensation practices are historically rooted in a "pay for performance" policy. ${ }^{142}$ In the 2011 Proxy Statement, the Cincinnati Board represented

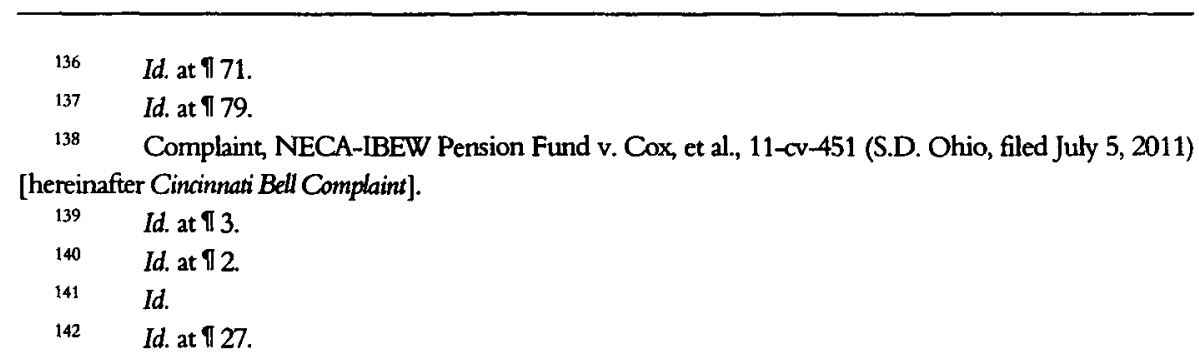


that "a significant portion of the total compensation for each of our executives is directly related to the Company's earnings and revenues and other performance factors" and "incentive compensation [is] based upon the achievement of company performance and individual performance goals." ${ }^{143}$ The Cincinnati Board advised shareholders to approve the executive compensation package for $2010 .{ }^{144}$ In May 2011, a majority of shareholders rejected Cincinnati Bell's executive compensation package for $2010 .{ }^{145}$

The plaintiffs allege that a pre-suit demand upon the Cincinnati Board is a "useless and futile action." ${ }^{146}$ The plaintiffs argue that the demand requirement is excused, because the defendants face a "substantial likelihood of liability for beach of loyalty."147 The plaintiffs also argue that the Cincinnati Board is not entitled to business judgment protection. ${ }^{148}$

The Complaint lists three causes of action. The first cause of action is for breach of fiduciary duty. The shareholders allege that the defendants breached their fiduciary duty of loyalty by approving the 2010 executive compensation package and by violating the company's own policy regarding "pay for performance" executive compensation. The second cause of action is against TWC for aiding and abetting breaches of fiduciary duties. The Complaint alleges that TWC "rendered substantial assistance" of the Cincinnati Board's breach of fiduciary duty. ${ }^{149}$ The third cause of action is for unjust enrichment. The Complaint alleges that the senior officers of the company have been unjustly enriched because the pay hikes received by the senior officers violated Cincinnati Bell's "pay-for-performance" policy. ${ }^{150}$

\section{Haberland v. Bulkeley ("Dex One")}

In the Dex One case, a shareholder derivative action was brought by shareholders on behalf of Dex One Corp. ("Dex One") against Dex One's

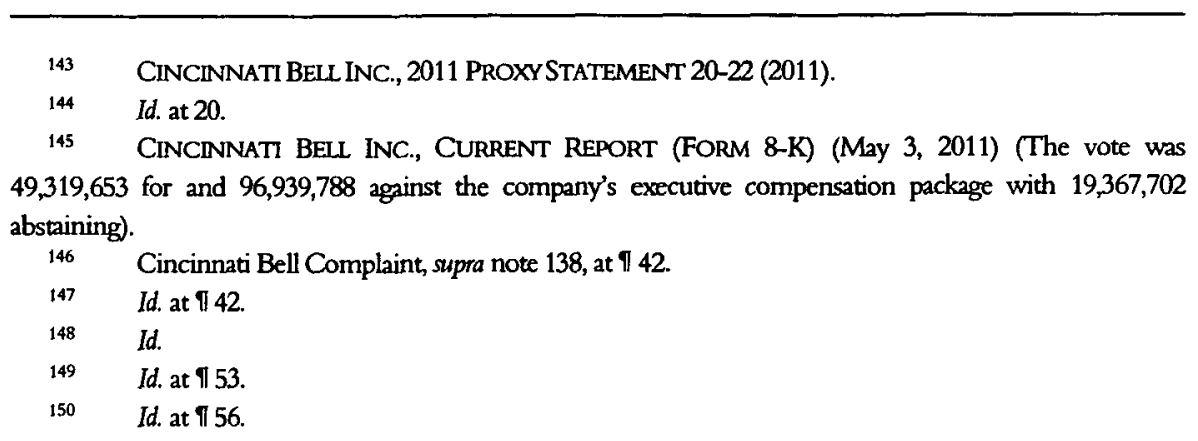


Board of Directors ("Dex One Board") and certain Dex One senior officers. ${ }^{151}$ The Complaint alleges the directors "breached their fiduciary duties by materially increasing 2010 compensation in the immediate wake of (a) the Company's bankruptcy ... [and] (b) the plummet of the Company's stock price."152

In the Complaint, the plaintiffs state that from February to December 2010 , Dex One's stock price decreased from $\$ 33.56$ per share to $\$ 7.46$ per share, a $78 \%$ decrease. ${ }^{153}$ The Complaint also alleges that Dex One was in bankruptcy from May 2009 to February 2010 and had a thirteen month suspension of public trading of its stock on the New York Stock Exchange ("NYSE"). ${ }^{154}$ The plaintiffs claim that even though the company suffered through bankruptcy and a dramatic decrease in their stock price, executive compensation was increased almost $300 \% .{ }^{155}$ The plaintiffs discuss how Dex One's executive compensation practices are historically rooted in a "pay for performance" policy. ${ }^{156}$ In the 2011 Proxy Statement, the Dex One Board represented that Dex One "align[s] executive pay with performance, both annual and long-term" and "strongly link[s] the interests of executives to those of the Company's shareholders." 157 The Dex One Board advised shareholders to approve the executive compensation package for 2011. ${ }^{158}$ In May 2011, a majority of shareholders rejected Dex One's executive compensation package for $2011 .{ }^{159}$

The plaintiffs allege that a pre-suit demand upon the Dex One Board is excused, because there is doubt that the Dex One Board's decision to increase 2010 executive compensation was a protected business judgment. ${ }^{160}$ The plaintiffs also argue that the Dex One Board is interested in the litigation "because there is substantial likelihood that they will be liable for their conduct."

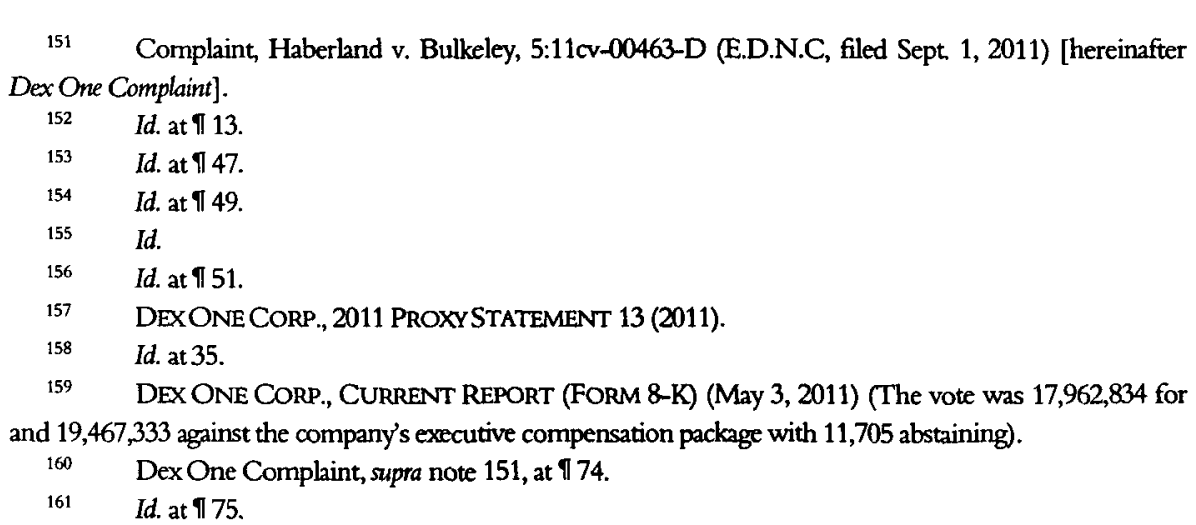


The Complaint lists four causes of action. The first cause of action is for breach of fiduciary duty. The shareholders allege that the defendants breached their fiduciary duties of care, loyalty, good faith, and candor for the issuance false and misleading statements. ${ }^{162}$ The second cause of action is also for breach of fiduciary duty. The shareholders allege that the defendants breached their fiduciary duties of care, loyalty, good faith, and candor by approving the 2010 executive compensation package and by violating the company's own policy regarding "pay for performance" executive compensation. ${ }^{163}$ The third cause of action is also for breach of fiduciary duty. The shareholders allege that the defendants breached their fiduciary duties of care, loyalty, good faith, and candor by failing to respond to the negative "say on pay" vote. ${ }^{164}$ The fourth cause of action is for unjust enrichment. The Complaint alleges that the senior officers of the company have been unjustly enriched because the pay hikes received by the senior officers violated Dex One's "pay for performance" policy. ${ }^{165}$

\section{What We Have Learned}

It is instructive to look at the derivative lawsuits filed so far concerning "say on pay" votes on executive compensation under the Dodd-Frank Act. By examining the cases, there are five areas of concern for all companies that are subject to the provisions of the Dodd-Frank Act. First, companies must be aware that even though the "say on pay" votes on executive compensation are explicitly advisory and do not add or modify any exsiting fiduciary duties of a company or its board of directors, shareholders are still filing derivative lawsuits on behalf of the company. Second, all the companies involved in the derivative lawsuits are alleged to have a publicly acknowledged "pay for performance" executive compensation structure. Third, the plaintiffs argue that demand is futile because the directors for the companies are "interested" in the litigation and face a substantial likelihood that they will be liable for their conduct and also argue that the negative "say on pay" votes are evidence that the executive compensation packages are not in the shareholders' best interests and, therefore, rebut the "business judgment rule" presumption. Fourth, companies need to be aware that institutional shareholders are casting most of the "say on pay" votes on executive compensation. Fifth,

$\begin{array}{ll}162 & \text { Id. at } \ 87-91 . \\ 163 & \text { Id. at } \uparrow 92-98 . \\ 164 & \text { Id. at } \Upsilon 99-105 . \\ 165 & \text { Id. at } \uparrow 106-09 .\end{array}$


executive compensation consultants are being included as defendants under a theory of "aiding and abetting" the directors in breaching their fiduciary duties.

\section{Shareholders Bringing Claims Despite "Say on Pay" Votes Being Advisory}

Companies should be aware that shareholders are bringing derivative claims based on negative "say on pay" votes on executive compensation, even though the votes are specifically advisory. The Dodd-Frank Act makes clear that the "say on pay" votes are merely advisory and are not binding on a company or its board of directors. ${ }^{166}$ The "say on pay" vote may also not be construed as overruling a decision by a company's board of directors. It cannot change or add to the fiduciary duties of a company's board of directors and it may not restrict or limit the ability of shareholders to make proposals for inclusion in proxy materials related to executive compensation. ${ }^{167}$ The Dodd-Frank Act does not provide for any specific remedy for shareholders if a company declines to change its executive compensation structure following a negative "say on pay" vote by shareholders.

It is instructive to look at the percentage of companies that received negative "say on pay" votes in 2011. As of June 2011, 2293 of the Russell $3000^{168}$ companies had held "say on pay" votes. ${ }^{169}$ Shareholders returned negative "say on pay" votes at only 45 , or $1.9 \%$, of these companies. ${ }^{170}$ Out of these 45 negative "say on pay" votes, 7 have resulted in shareholder derivative lawsuits. ${ }^{171}$ This number reflects that about $15 \%$ of the

16615 U.S.CA. $\$ 78 \mathrm{n}-1$ (c) (West 2012).

167 Id.

168 The Russell 3000 Index measures the performance of the largest 3000 U.S. companies representing approximately $98 \%$ of the investable U.S. equity market. It includes companies such as: Exxon Mobil, Apple, Chevron, AT\&T, GE, and Microsoft. See RUSSELL 3000 INDEX, http//www.russell.com/Indexes/dat/fact_sheets/us/Russell_3000_Index.asp (last visited Dec. 20, 2011).

169 See James D. C. Barrall \& Alice M. Chung, Say on Pay and Related Advisony Vote Proposals, LATHAM\&WATKINS, (Sept. 12, 2011), http//www.lw.com/Resources.aspx?page=FirmPublicationDetail \&publication $=4337$. It is important to note that in 2010 , over 600 companies held "say on pay" votes and only $3(0.5 \%)$ companies failed to obtain shareholder approval. See Institutional Shareholder Services, 2010 U.S. Postseason Repont, ISS, available at http//www.issgovernance.com/files/private/ISS_USPostSeasonReport.pdf.

170 See Equilar Report, supra note 41.

171 See Bradley J. Andreozzi, Update on Lausuits in the Wake of Say-On-Pay, DRINKERBIDDLE (Oct. 13, 2011), http://www.mondaq.com/unitedstates/ $/$ /148946/Securities/Update+On +Lawsuits + In + The +Wake+ Of + SayOnPay. 
companies that received a negative "say on pay" vote are facing shareholder derivative lawsuits.

The percentage of negative votes has also not affected whether the shareholders bring a claim based on a negative "say on pay" vote on executive compensation. In the Jacobs Engineering case, $55 \%$ of the shareholders voted against the executive compensation plan. ${ }^{172}$ In the Beazer Homes case, $54 \%$ of the shareholders voted against the executive compensation plan. ${ }^{173}$ In the Umpqua Holdings case, $64 \%$ of the shareholders voted against the executive compensation plan. ${ }^{174}$ In the Hercules Offshore case, $59 \%$ of the shareholders voted against the executive compensation plan. ${ }^{175}$ In the Cincinnati Bell case, $70 \%$ of the shareholders voted against the executive compensation plan. ${ }^{176}$ In the Janus Capital case, $60 \%$ of the shareholders voted against the executive compensation plan. ${ }^{177}$ In the Dex One case, $52 \%$ of the shareholders voted against the executive compensation plan. ${ }^{178}$ These cases show that as long as a majority of the shareholders vote against the executive compensation plan, a derivative suit is being filed. To date, there has not been a shareholder derivative suit filed against a company and its board of directors following a positive "say on pay" vote on executive compensation.

\section{Companies' "Pay for Performance" Executive Compensation Structures}

Shareholders consider pay for performance an integral aspect of executive compensation. ${ }^{179}$ According to a 2011 ISS survey "94 percent of institutional investor respondents believed that pay-for-performance plays either a 'critical' or 'important' role in evaluating executive compensation." 180 Experts have also emphasized "pay for performance" as the optimal form of compensation. ${ }^{181}$

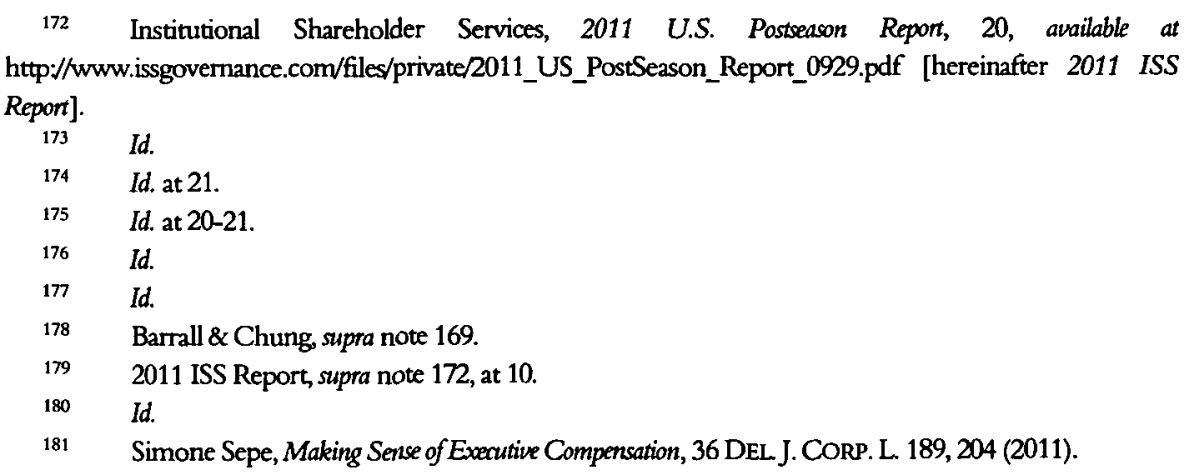


All of the derivative claims discussed in this article include a claim that a company violated its "pay for performance" policy. Specifically, the plaintiffs assert a disconnect between pay and performance by looking at weakening corporate financial performance and increasing executive compensation. ${ }^{182}$ Plaintiffs in these cases have also relied on ISS recommendations concerning "say on pay" voting. ${ }^{183}$ During the 2011 Proxy Season, of the 340 recommendations by ISS to vote negatively on the proposed executive compensation, 177 , or about $52 \%$, of the negative ISS recommendations were based upon a company's "pay for performance" misalignment. ${ }^{184}$

As discussed above, all the companies have some type of "pay for performance" executive compensation structure. In Jacobs Engineering's 2011 Proxy Statement, the Jacobs Board represented that Jacobs Engineering's "executive compensation program has been designed to promote a performance-based culture and align the interests of executives with those of shareholders by linking a substantial portion of compensation to the Company's performance." ${ }^{285}$ In Beazer Homes' 2011 Proxy Statement, the Beazer Board represented that their "core compensation objective continues to be that we will pay for performance." 186 In Umpqua Holdings' 2011 Proxy Statement, the Umpqua Board represented that their "executive compensation is designed to recognize superior operating performance ... Our executive compensation philosophy is simple: we pay competitive base salaries and we strongly reward performance." ${ }^{\prime 87}$ In Hercules Offshore's 2011 Proxy Statement, the Hercules Board represented that their "compensation committee will continue to design compensation arrangements with the objectives of emphasizing pay for performance."188

In Janus Capital's 2011 Proxy Statement, the Janus Board represented that their executive compensation program was designed to "attract, motivate and retain highly qualified executives ... reward strong

Kyoto Takahasi Lin \& Gillian Emmett Moldowan, Perceived Pay-for-Performance Disconnect Brings Say-on-Pay Shareholder Derivative Suits, Davis POLK BRIEFING: GovernanCE (June 24, 2011, 12:29 PM), http://www.davispolk.com/briefing/corporategovernance/blog.aspx?entry=69.

183 See e.g. UMPQUA HOLDINGS CORP., CURRENT REPORT, (FORM 8-K) (April 22, 2011) ("The ISS report found a 'disconnect' between out CEO compensation in 2010 and the company's total shareholder return").

1842011 ISS Report, supra note 172, at 5.

185 JaCOBS ENGINEERING Grour, INC., 2011 PRoXy STATEMENT 10 (2011).

186 BEAZER HOMES, USA, INC., 2011 PROXYSTATEMENT 31 (2011).

187 UMPQUA HOLDINGS CORP., 2011 PROXYSTATEMENT 30 (2011).

188 HerCULES OFFSHORE, INC., 2011 PROXYSTATEMENT 43 (2011). 
performance ... [and] promote a performance-based culture with individual compensation levels varying significantly from year to year based on changes in business and individual performance." ${ }^{\text {189 }}$ In Cincinnati Bell's 2011 Proxy Statement, the Cincinnati Board represented that their executive compensation program is "based upon the achievement of company performance and individual performance goals" and is "tied to the achievement of short-term and long-term performance objectives, principally the Company's earnings." ${ }^{\text {"190 }}$ In Dex One's 2011 Proxy Statement, the Dex One Board represented that their executive compensation program "align[s] executive pay with performance, both annual and long-term" and "strongly link[s] the interests of executives to those of the Company's shareholders." 191

Companies must be aware that shareholders may use language in their policies, which link executive compensation to company performance, against a company and its board of directors in a derivative claim. Later in this article, I provide advice to companies to minimize any potential exposure arising from language concerning executive compensation included in their Proxy Statement or any other public filings. ${ }^{192}$

\section{Business Judgment Rule and Director Independence}

Demand is excused in situations where a complaint raises "a reasonable doubt as to (i) director disinterest or independence or (ii) whether the directors exercised proper business judgment in approving the challenged transaction." 193

Courts have stated that one way to excuse a failure to make a demand on the board of directors is for plaintiffs to plead with particularity facts creating a reasonable doubt that the directors are disinterested and independent. ${ }^{194}$ The plaintiffs state that the directors face a substantial likelihood of liability and are interested in the outcome of the litigation because the directors of each company approved the executive

189 JaNus CaptTal Group, INC., 2011 Proxy STATEMENT 33 (2011).

190 CINCINNATI BELL INC., 2011 ProXYSTATEMENT 20-22, 32 (2011)

191 DEXONE CORP., 2011 PROXYSTATEMENT 13 (2011).

192 See infra Section IV(A).

193 RCM Sec. Fund, Inc. v. Stanton, 928 F.2d 1318, 1330 (2d Cir. 1991) (citing Grobow v. Perot, 539 A.2d 180, 188-89 (Del. 1988)).

194 Jay M. Zitter, Circumstances Excusing Demand Upon Board of Directors that is Otherwise Prerequisite to Bringing of Stockholder's Derivative Suit on Behalf of Corporation, 42 A.L.R. 6th 1 passim (2009). 
compensation structure being challenged and then recommended shareholder approval of the executive compensation structure. ${ }^{195}$

Generally, to show that directors are "interested," the plaintiffs must show that divided loyalties are present or that a director has received or is entitled to receive a personal financial benefit from the challenged transaction. ${ }^{196} \mathrm{~A}$ lack of candor in describing the CEO's compensation may also render the directors "interested" for purposes of excusing demand. ${ }^{197}$ Shareholders must allege that directors could not impartially and independently consider a demand. ${ }^{198}$ The plaintiffs are using the fact that the directors not only approved the executive compensation structure being challenged, they also recommended that the shareholders approve it. They argue that the directors would not proceed with an action that would invalidate a decision that they approved. The plaintiffs in Beazer Homes, Hercules Offshore, Umpqua Holdings, Cincinnati Bell, Jacobs Engineering, and Dex One also allege that because a director also served as an executive officer of the company and would receive a direct benefit of the challenged executive compensation structure, they could not be "independent." 199

Demand is also excused in situations where the complaint raises "a reasonable doubt as to ... whether the directors exercised proper business judgment in approving the challenged transaction." 200 A board of directors is protected by the "business judgment rule" and courts "will not inquire into the wisdom of actions taken by a director in the absence of fraud, bad faith, or abuse of discretion." 201 "[T] overcome by proof that the director breached his fiduciary duty to the corporation-his duty of loyalty and his duty to exercise due care in its performance." 202 The plaintiffs state that the negative "say on pay" votes

\footnotetext{
195 See supra Section III(B).

196 See Pogostin v. Rice, 480 A.2d 619, 624 (Del. 1984); see also Litt v. Wycoff, No. Civ. A. 19803-NC, 2003 WL 1794724, at *3 (Del. Ch. Mar. 28, 2003).

19 In re infoUSA, Inc. Shareholders Litigation, 953 A.2d 963, 990-91 (Del. Ch. 2007).

198 See, e.g., Beam ex rel. Martha Stewart Living Omnimedia, Inc. v. Stewart, 845 A.2d 1040, 1046 n.8 (Del. 2004).

199 See supra Section III(B).

200 RCM Sec. Fund, Inc. v. Stanton, 928 F.2d 1318, 1330 (2d Cir. 1991) (citing Grobow v. Perot, 539 A.2d 180, 188-89 (Del. 1988)).

201 Radol v. Thomas, 772 F.2d 244, 256 (6th Cir. 1987); see also Gearhart Indus. v. Smith Int'l, 741 F.2d 707 (5th Cir. 1984 ); In re Abbott Labs. Derivative S'Holders Litig., 325 F.3d 795 (7th Cir. 2003); Hanson Trust PLC v. ML SCM Acquisition, Inc., 781 F.2d 264 (2d Cir. 1986).

${ }_{202}$ CDX Liquidating Trust v. Venrock Assocs., 640 F.3d 209, 215 (7th Cir. 2011); see also Mukamal v. Bakes, 378 Fed. Appx. 890, (11th Cir. 2010); Edelman v. Fruehauf Corp., 798 F.2d 882 (6th Cir. 1986).
} 
were evidence that the executive compensation packages were not the shareholders' best interests and, therefore, rebutted the "business judgment rule" presumption.

For example, in the Cincinnati Bell Complaint, the plaintiffs contended that the negative "say on pay" vote was evidence that the executive compensation package was not in the shareholders best interests and, therefore, the decision to increase executive compensation was not entitled to "business judgment rule" protection. ${ }^{203}$ Likewise, in the Janus Capital Complaint, the plaintiffs contend that the negative "say on pay" vote was evidence that rebutted the "business judgment rule" presumption. ${ }^{204}$ All of the other Complaints include similar language, discussing how the negative "say on pay" vote was evidence that rebutted the "business judgment rule" presumption.

Plaintiffs in the Cincinnati Bell and Umpqua Holdings cases also argued that they were using their "independent business judgment" when voting on an executive compensation structure. In Cincinnati Bell, the plaintiffs state that their "shareholder base consists primarily of sophisticated institutional investors ... [and] these types of sophisticated shareholders possess the experience, expertise and resources to assess ... whether executive compensation is in their best interests as shareholder owners." ${ }^{205}$ In Umpqua Holdings, the plaintiffs state that "by voting against the Umpqua Board's 'say-on-pay' resolution, Umpqua shareholders ... concluded, in their independent business judgment, that the 2010 pay hikes approved by the Umpqua Board ... were not in the best interest of Umpqua and/or its shareholders. ${ }^{206}$

Based upon the facts listed above, many questions remain unanswered. If shareholders return a negative "say on pay" vote in a case where ISS made a positive recommendation, can the company still argue that they are using their independent business judgment? In the opposite case, could a shareholder bring a derivative claim if the shareholders return a positive "say on pay" vote, but the ISS made a negative recommendation? Neither of these cases has arisen yet, but with "say on pay" votes in their infancy, it would not be unexpected in the coming years.

203 Cincinnati Bell Complaint, supra note 138, at 142

204 Janus Capial Complaint, supra note 123, at II 13.

205 Cincinnati Bell Complaint, supra note 138, at 134.

206 Umpqua Holdings Complaint, supra note 94, at $\$ 42$. 


\section{Institutional Shareholders}

Most of the "say on pay" votes on executive compensation are being cast by institutional shareholders. ${ }^{207}$ Approximately $73 \%$ of the publicly traded equity value in U.S. public corporations is held by institutional shareholders. ${ }^{208}$ During the last twenty years, institutional investors have steadily expanded their presence in the largest U.S. corporations, despite the significant effect of the economic recession on their equity portfolio. ${ }^{209}$

Institutional investors, while alleging decisions based on their own "independent business judgment," usually receive advice from shareholder advocates. The largest of these advocates is ISS. ${ }^{210}$ ISS is a provider of proxy advisory and corporate governance solutions to financial market participants. ${ }^{211}$ In 2011, ISS issued recommendations on 3,009 "say on pay" proposals. ${ }^{212}$ Out of those 3,009 recommendations, ISS only recommended voting against the "say on pay" proposal for 340 , or about $11 \%$, of those companies. ${ }^{213}$ ISS recommended negative "say on pay" votes "due to pay-for-performance misalignment ... [and] problematic pay practices." ${ }^{214}$ Out of the 340 negative ISS recommendations, shareholders returned negative "say on pay" votes at 38 , or $10 \%$, of those companies. ${ }^{215}$ It is important to note that ISS recommended voting against "say on pay" proposals for all the companies that have filed derivative claims. ${ }^{216}$

Generally, institutional shareholders do not owe any duties to one another or the corporations in which they own shares. ${ }^{217}$ Institutional

207 Joseph E. Bachelder, III, Say-on-Pay Under Dodd-Frank, THE HARVARD LAW SCHOOL FORUM ON CORPORATE GOVERNANCE AND FINANCIAL REGULATION (Sept. 17, 2011).

208 Matteo Tonello and Stephan Robimov, The 2010 Institutional Investment Report: Trends in Asset Allocation and Ponfolio Composition, 27, auailable at http//www.conference-board.org/publicatons/ publicationdetail.cfn?publicationid=1872. Mutual funds make up the largest group of institutonal shareholders based upon the value of their holdings. See Bachelder, supra note 207.

209 Tonello and Robimov, supra note 208, at 27.

210 See ISS, http//www.issgovernance.com/. “ISS' services include objective govenance research and analysis, end-to-end proxy voting and distribution solutions, turnkey securities class-action claims management, and reliable governance data and modeling tools." Id.

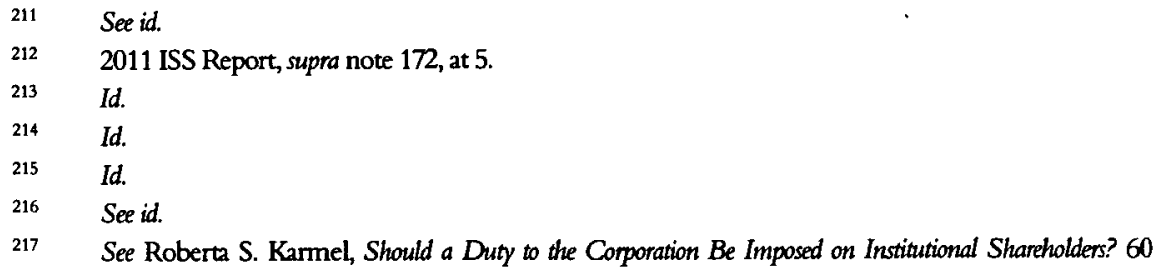


shareholders are "not investing their own capital, but the capital of others to whom they owe fiduciary duties. There is a potential and sometimes an actual conflict between the beneficiaries of an institutional investor and the shareholders and other constituents of corporations in which they invest."218 Empirical evidence also shows that institutional investors do not keep stocks for as long as non-institutional shareholders. ${ }^{219}$ However, "institutions have a duty to invest assets of their beneficiaries prudently and such prudence may benefit the financial structures and operations of portfolio companies."220

\section{Executive Compensation Consultants are Not Immune from Suit}

Companies' reliance on executive compensation consultants is a common practice. ${ }^{221}$ However, it was not until recently that compensation consultations have been named in executive compensation shareholder derivative suits. Plaintiffs in all but two of the shareholder derivative suits raised claims for aiding and abetting the board of directors' alleged breaches of fiduciary duties and for breach of contract. ${ }^{222}$ It is important to note that courts have been more wary of executive compensation consultants not acting in the shareholders' best interests. In a case from the Southern District of New York, the District Court stated that executive compensation consultants had "a skewed focus when it comes to executive compensation ... generally favoring [] larger compensation practices, while rarely taking into account of limits that a reasonable shareholder might place on such expenditures."223

The plaintiffs are bringing claims against the executive compensation consultants under two different theories of liability. The first theory is that the compensation consultants "aided and abetted" the directors' breaches of fiduciary duties. In the Jacobs Engineering Complaint, the plaintiffs state that the Jacobs Board violated the fiduciary duties of

\footnotetext{
BUS. LAW 1 (Nov. 2004).

218 Id.

219 See Bachelder, supra note 207.

220 Id. (citing Gregg v. Transp. Workers of Am. Int'l, 343 F.3d 833, 840-41 (6th Cir. 2003)).

221 Beth Boland, et al., Say on Pay': Shareholder 'No' Votes Now Leading to Derivative Actions Challenging Executive Compensation, BINGHAM (July 7, 2011), http//www.bingham.com/Media.aspx?MediaID =12582 (last visited Dec. 20, 2011).

222 Plaintiffs in the Janus Capital and Dex One cases did not bring claims against the executive compensation consultants.

223 SEC v. Bank of Am. Corp., 09 Civ. 6829, 2010 U.S. Dist. LEXIS 15460, at *14 (S.D.N.Y.
} Feb. 22, 2010). 
candor, good faith, and loyalty, and that the consultants "acted with knowledge of the wrongdoing [], substantially assisted the accomplishment of that wrongdoing and was aware of its overall contribution to and furtherance of the wrongdoing."224 The Hercules Offshore Complaint, Beazer Homes Complaint, Cincinnati Bell Complaint, and Umpqua Holdings Complaint all contain similar language.

The second theory alleged is for breach of contract. In the Jacobs Engineering Complaint, the plaintiffs state that the executive compensation consultants assisted the Jacobs Board with setting the level of executive compensation payments. The plaintiffs assert that "[i]n light of the Jacobs' dismal financial results, increasing the amounts of compensation paid, or to be paid to Jacobs executives ... was unreasonable and not in good faith" and that because of this, the executive compensation consultants "breached its contract with Jacobs to render competent and sound advice and service regarding [] executive compensation." 225 The Hercules Offshore Complaint, Beazer Homes Complaint, Cincinnati Bell Complaint, and Umpqua Holdings Complaint all contain similar language.

Plaintiffs in these cases will face a high hurdle when litigating claims against the compensation consultants. For an "aiding and abetting" claim to succeed, the plaintiffs must "allege: (1) the existence of a fiduciary relationship, (2) that the fiduciary breached its duty, (3) that a defendant, who is not a fiduciary, knowingly participated in the breach, and (4) that damages to the plaintiff resulted from the concerted action of the fiduciary and the non-fiduciary."226 This means that a court will not only need to find that the board of directors breached their fiduciary duties, but also that the compensation consultants knowingly participated in the breach. For the breach of contract claims, the courts will look at the specific language of the contracts to determine if there has been any breach. Many commentators have opined that the inclusion of executive compensation consultants as defendants is designed to create more leverage to increase the settlement value of the shareholder derivative suits. ${ }^{227}$

\footnotetext{
224 Jacobs Engineering Complaint, supra note 61, 凤 72.

225 Id. $₫ 75$.

226 Mukamal v. Bakes, 378 Fed. Appx. 890, 902 (11th Cir. 2010) (Delaware law); see also Miles Farm Supply, LLC v. Helena Chem. Co., 595 F.3d 663 (6th Cir. 2010) (Kentucky law); see also CDX Liquidating Trust v. Venrock Assocs., 640 F.3d 209 (7th Cir. 2011) (Illinois law); see also Sharp Int'l Corp. v. State St. Bank \& Trust Co., 403 F.3d 43 (2d Cir. 2005) (New York law); see also Broussard v. Meineke Disc. Muffler Shops, 155 F.3d 331 (4th Cir. 1998) (North Carolina law).

$227 \quad$ See Boland, supra note 221.
} 


\section{Court Rulings}

As of October 2, 2012, there have been rulings in three of the cases discussed above. In the Cincinnati Bell case, the U.S. District Court for the Southern District of Ohio ("Ohio Court") denied the defendants' Motion to Dismiss. ${ }^{228}$ In the Beazer Homes case, the Fulton County Superior Court ("Georgia Court") granted the defendants' Motion to Dismiss. ${ }^{229}$ Both of these cases will be discussed at length below. In the Umpqua Holdings case, the U.S. District Court for the District of Oregon ("Oregon Court") denied the defendants' Motion to Dismiss. ${ }^{230}$

\section{Cincinnati Bell Order}

On September 20, 2011, the Ohio Court denied the defendants' Motion to Dismiss. The defendants' motion was decided under Ohio law. ${ }^{231}$ In the Cincinnati Bell Order, the defendants first asked the Ohio Court to dismiss the suit, claiming that they were protected by the business judgment rule. ${ }^{232}$ The Ohio Court held that the plaintiffs adequately pleaded a claim of breach of fiduciary duty. ${ }^{233}$

Directors owe the duties of loyalty and care to the corporation. ${ }^{234}$ "The duty of loyalty requires that directors perform their duties 'in good faith, in a manner the director reasonably believes to be in or not opposed to the best interests of the corporation." ${ }^{235}$ The Ohio Court went on to state that informed decisions on compensation by disinterested directors are presumed to be protected by the business judgment rule ${ }^{236}$ and that

228 Order Deny'g Def.'s Motion to Dismiss, NECA-IBEW Pension Fund v. Cox, 11-cv-451, 2011 WL 4383368 (S.D. Ohio, Sept. 20, 2011) [hereinafter Cincinnati Bell Order].

229 Order Granting Def.'s Motion to Dismiss, Teamsters Local 237 v. McCarthy, 2011-cv-197841 (Ga. Super. Ct., Sept. 16, 2011) [hereinafter Beazer Homes Order].

230 Order Granting Def.'s Motion to Dismiss, Plumbers Local No. 237 v. Davis, 11-cv-633, 2012 WL 104776 (D. Or., Jan. 11, 2012) [hereinafter Umpqua Holdings Order].

231 See Kamen v. Kemper Fin. Serv. Inc., 500 U.S. 90, 98 (1991).

232 Cincinnati Bell Order, supra note 228, at *4.

233 Id.

234 Id. at $\star 2$ (citing Radol v. Thomas, 772 F.2d 244, 257 (6th Cir. 1987) (courts "will not inquire into the wisdom of actions taken by a director in the absence of fraud, bad faith, or abuse of discretion.")).

235 Id. (quoting Ohio Rev. Code Ann. $\$ 1701.59$ (B) (West 2011)). Under Ohio law "directors will face liability only if it is shown by clear and convincing evidence that their actions were undertaken with 'a deliberate intent to cause injury to the corporation' or 'reckless disregand for the best interests of the corporation." Id. (quoting Ohio Rev. Code Ann. \$1701.59(D) (West 2011)).

236 Id. (citing Prod. Res. Group LLC v. NCT Group, Inc., 863 A2d 772, 779 (Del. Ch. 2004)). 
the plaintiffs bear the burden to present facts that rebut the business judgment rule's presumption of good faith of directors. ${ }^{237}$

The Ohio Court emphasized that the "business judgment rule imposes a burden of proof, not a burden of pleading."’238 "When plaintiffs allege a breach of fiduciary duty, 'the business judgment rule would impose on [p]laintiffs a burden at trial to present evidence to rebut the presumption the rule imposes. However, [p]laintiffs are not likewise obligated to plead operative facts in their complaint that would rebut the presumption."'339 The Ohio Court found that the plaintiffs had adequately pleaded that the Cincinnati Board was not protected by the business judgment rule for the 2010 executive pay structure. ${ }^{240}$ The Ohio Court further stated that the Complaint provided factual allegations that raised a plausible claim that the executive compensation structure approved by the directors, in a time that the company's financial performance was declining, violated Cincinnati Bell's "pay for performance" policy and were not in the best interests of the shareholders and constituted an "abuse of discretion and/or bad faith."241

The defendants also asked the Ohio Court to dismiss the suit, because the plaintiffs did not make a demand upon the directors to sue themselves. ${ }^{242}$ The Ohio Court held that the plaintiffs were excused from the pre-suit demand. ${ }^{243}$ Ohio law permits "a shareholder to proceed with a derivative suit without first making a demand if the shareholder can demonstrate that the demand would have been futile. ${ }^{244}$

To demonstrate futility, the plaintiffs have the burden of showing "that 'the directors minds are closed to argument and that they cannot properly exercise their business judgment in determining whether the suit should be filed." "245 Ohio courts have "consistently rejected the idea that demand is always futile when the directors are targeted as the wrongdoers of the suit." 246 However, the Ohio Court also stated that "demand is

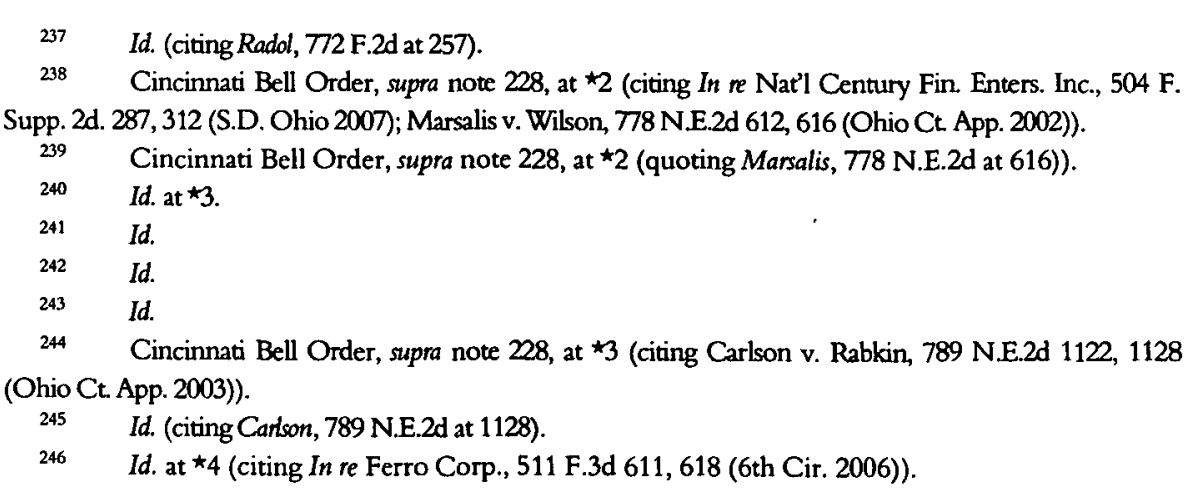


presumptively futile 'where the directors are antagonistic, adversely interested, or involved in the transactions attacked"'247 and that under Delaware law, a "pre-suit demand if excused when plaintiff s allegations create a reasonable doubt that the challenged transaction is the result of a valid business judgment." ${ }^{248}$

The Ohio Court found that the plaintiffs had pleaded specific facts that gave reason to doubt that the directors could make unbiased, independent business judgments about whether to bring a lawsuit. The Ohio Court further found that "the defendants [] approved the pay hikes and bonuses" and that the "directors did not merely approve the transaction, they also recommended to the shareholders that the shareholders approve the compensation."249 Because the plaintiffs demonstrated facts to show that the defendants "devised the challenged compensation, approved the compensation, recommended shareholder approval of the compensation, and suffered a negative shareholder vote on the compensation," the Ohio Court found there was reason to doubt the defendants could exercise their independent business judgment and concluded that the plaintiffs' allegations created doubt that the challenged transactions were the result of a valid business judgment and that the defendants possessed a "disqualifying interest sufficient to render pre-suit demand futile."250 The Ohio Court also found that since the plaintiffs pleaded sufficient facts to show the defendants breached their fiduciary duties to the corporation, the plaintiffs had also sufficiently pleaded a claim for unjust enrichment. ${ }^{251}$

\section{Beazer Homes Order}

On September 16, 2011, the Georgia Court granted the defendants' Motion to Dismiss. The defendants' motion was decided under Delaware law. ${ }^{252}$ In the Beazer Homes Order, the defendants asked the Georgia Court to dismiss the suit, claiming that the plaintiffs lacked standing to bring suit and that the plaintiffs failed to make a pre-suit demand on the

\footnotetext{
247 Id. (quoting Ferro, 511 F.3d at 618).

248 Id. (citing McCall v. Scott, 239 F.3d 808, 816 (6th Cir. 2001)).

249 Id.

$250 \quad$ Id.

251 Id. at *5 (citing Jackson Nat'l. Life Ins. Co. v. Kennedy, 741 A.2d 377, 394 (Del. Ch. 1999)).

252 See Beazer Homes Order, supra note 229, at 4 (citing Diedreich v. Miller \& Meier \& Assoc. Architects \& Planners, Inc., 334 S.E.2d 308, 310 (Ga. 1985)).
} 
Beazer Board. ${ }^{253}$ The Georgia Court held that the dismissal was warranted on each of the grounds asserted by the defendants. ${ }^{254}$

To have standing to sue derivatively, under Delaware law, plaintiffs must have owned a company's stock "contemporaneously with the alleged wrongful conduct about which they are complaining and to have held the stock continuously since that time and throughout the duration of the lawsuit." ${ }^{\text {255 }}$ Plaintiffs are required to allege in the Complaint that they satisfy the contemporaneous and continuous requirement of stock ownership. ${ }^{256}$

In the Beazer Homes Complaint, the plaintiffs alleged that they had continuously held Beazer Homes stock since May 2010. ${ }^{257}$ The Georgia Court found that the decision that determined the 2010 executive compensation structure that the plaintiffs were challenging occurred prior to May 2010 and, therefore, the plaintiffs did not have standing to bring the shareholder derivative lawsuit. ${ }^{258}$ The Georgia Court specifically stated that "[p]laintiffs bought stock after Beazer's Compensation Committee had established Beazer executives' 2010 base salaries and [] performance goals" and that the Georgia Court was not persuaded that "[p]laintiffs' purchase of stock after the conditions on which challenged pay would be awarded were established, albeit before the pay was actually awarded pursuant to those pre-established terms, suffices to satisfy the letter and spirit of the contemporaneous and continuous stock ownership requirement." 259

The Georgia Court also held that the plaintiffs failed to adequately allege excuse for their failure to make a pre-suit demand on the Beazer Board. ${ }^{260}$ Under Delaware law, the plaintiffs must "make a pre-suit demand on the company's board that it investigate and evaluate whether to bring the claims or to plead particularized facts demonstrating legal excuse from the demand requirement."261 Demand excuse allegations "'must comply with stringent requirements of factual particularity that differ substantially from the permissive notice pleadings ... [and] is not

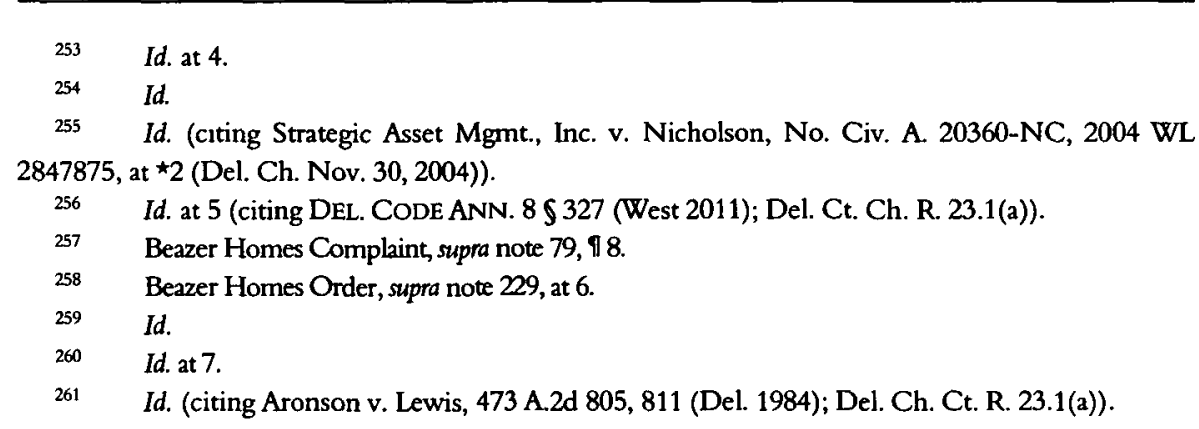


satisfied by conclusory statement or mere notice pleading."”262 In cases where a claim is challenging a decision by a company's board of directors, the test in Aronson will apply. ${ }^{263}$ Under Aronson, "where officers and directors are under an influence which sterilizes their discretion, they cannot be considered proper persons to conduct litigation on behalf of the corporation. Thus, demand would be futile."264 The Court in Aronson also "recognized that demand futility is inextricably bound to issues of business judgment, but stated the test to be based on allegations of fact, which, if true, 'show that there is a reasonable inference' the business judgment rule is not applicable for purposes of a pre-suit demand."265

The Georgia Court first found that the plaintiffs' allegations that the Beazer Board breached its fiduciary duties by approving the challenged executive compensation package and recommending it to the shareholders were unpersuasive. ${ }^{266}$ The Georgia Court held that the plaintiffs failed to meet the first prong of the Aronson test, because only one member of the Beazer Board was also an executive officer and alleged to have received the compensation that plaintiffs were challenging and, therefore, the plaintiffs did not allege that demand was excused because a majority of Beazer Homes' directors lacked independence. ${ }^{267}$

The Georgia Court next analyzed whether the Beazer Board's decision on executive compensation received protection under the business judgment rule. The business judgment rule "is a presumption that in making a business decision the directors of a corporation acted on an informed basis, in good faith and in the honest belief that the action taken was in the best interests of the company." ${ }^{268}$ The plaintiffs argue that the adverse "say on pay" vote by a majority of shareholders constituted evidence that rebutted the presumption that the Beazer Board's decision approving the executive compensation package and

262 Id. (quoting Brehm v. Eisner, 746 A.2d 244, 254 (Del. 2000)). It is important to note that the plaintiffs are not required to plead evidence, only "particularized factual statements that are essential to the claim" Brehm, 746 A.2d at 254.

263 Beazer Homes Order, supra note 229, at 7-8.

264 Arronson, 473 A.2d at 814.

265 Id. (quoting Aronson, 466 A.2d at 381).

266 Beazer Homes Order, supra note 229, at 8.

267 Id.; Aronson, 473 A.2d at 816 ('Independence means that a director's decision is based on the corporate merits of the subject before the board rather than extraneous considerations or influences."); Pogostin v. Rice 480 A.2d 619, 624 (Del. 1984) (“Directorial interest exists whenever divided loyalties are present, or a director either has received, or is entitled to receive, a personal financial benefit from the challenged transaction which is not equally shared by the stockholders.").

268 Aronson v. Lewis, 473 A.2d 805, 812 (Del. 1984). 
recommending it to shareholders reflected a valid business judgment. ${ }^{269}$ The Georgia Court rejected the plaintiffs' arguments as unpersuasive. The Georgia Court held that "because the say on pay vote had not yet been held when the challenged decisions to approve the pay at issue and recommend that shareholders vote to approve it were made, the Beazer Board could not have considered the results of the vote in making those decisions." 270

The Georgia Court also held that plaintiffs' argument that they used their own "independent business judgment" to rebut the presumption of business judgment rule protection for the Beazer Board was not supported by Delaware law or the Dodd-Frank Act itself. ${ }^{271}$ The Georgia Court stated that the language of the Dodd-Frank Act "expressly preserved the pre-existing fiduciary duty framework concerning executive compensation decisions."272 Delaware law gives directors wide discretion to set executive compensation. ${ }^{273}$ The plaintiffs also argued that the negative "say on pay" vote was evidence that the Court could consider to rebut the "business judgment rule" presumption; however, the Georgia Court stated that " $[\mathrm{g}]$ iven that Delaware law, which the Dodd-Frank Act explicitly declined to alter, places authority to set executive compensation with corporate directors, not shareholders, this Court will not conclude that an adverse say on pay vote alone suffices to rebut the presumption of business judgment protection applicable to directors' compensation decisions. 274

The Georgia Court also held that the "aiding and abetting" claims against the executive compensation consultants ( $\mathrm{PwC}$ and Markson) must be dismissed, because the plaintiffs had not alleged any underlying breach of fiduciary duties by the Beazer Board. ${ }^{275}$ The Georgia Court also dismissed the unjust enrichment claim stating that "plaintiffs have not

\footnotetext{
269 Beazer Homes Complaint, supra note 79, 13.

270 Beazer Homes Order, supra note 229, at 10; see also In re Cox Radio, Inc. S'holders Litig., No. 4461-CVP, 2010 WL 1806616, at $\star 14$ (Del. Ch. May 6, 2010) ("While hindsight is generally $20 / 20$, it cannot be used to second guess the business judgment of Delaware directors.").

271 Beazer Homes Order, supra note 229, at 11.

$272 \quad$ Id.

273 Id.; Haber v. Bell, 465 A.2d 353, 359 (Del. Ch. 1983) (" [G]enerally directors have the sole authority to determine compensation levels."); Orban v. Field, No. Civ. A. 12829, 1997 WL 153831, at $\star 10$ (Del. Ch. Apr. 1, 1997) ("Where . . . a payment decision has been approved by a majority of disinterested directors, it is entitled to the protection of the business judgment rule.").

274 Beazer Homes Order, supra note 229, at 12 (emphasis in original).

275 Id. at 20; Globis Partners, L.P. v. Plumtree Software, Inc., No. 1577-VCP, 2007 WL 4292024 , at $\star 15$ (Del. Ch. Nov. 30, 2007) (dismissing aiding and abetting claim where plaintiff failed to state a claim for underlying breach of fiduciary duty).
} 
alleged that the compensation awarded to the Beazer executives ... was in any way inconsistent with those executives' achievement of performance targets. ${ }^{276}$

\section{Umpqua Holdings Order}

On January 11, 2012, the Oregon Court granted the defendants' Motion to Dismiss. The defendants' motion was decided under Oregon law. ${ }^{27}$ In the Umpqua Holdings Order, the defendants asked the Oregon Court to dismiss the suit, claiming that the plaintiffs lacked standing to bring suit and that the plaintiffs failed to make a pre-suit demand on the Umpqua Board. ${ }^{278}$ The Oregon Court held that the dismissal was warranted on each of the grounds asserted by the defendants. ${ }^{279}$

To have standing to sue derivatively, the plaintiffs must have owned shares in the corporation at the time of the disputed transaction. Second, the plaintiffs must "allege with particularity the efforts, if any, made by the plaintiff to obtain the action the plaintiff desires from the directors." 280 If a demand was not made to the board, the plaintiffs may still initiate an action where it is shown that such demand would have been futile. ${ }^{281}$

The Oregon Court held that the plaintiffs failed to adequately allege excuse for their failure to make a pre-suit demand on the Umpqua Board. In cases where a claim is challenging a decision by a company's board of directors, the test in Aronson will apply. ${ }^{282}$ The first prong of the Aronson test is "whether 'a shareholder [has pleaded] with particularity facts that establish that demand would be futile because the directors are not independent or disinterested.' The second prong of the test is whether 'a

\footnotetext{
276 Beazer Homes Order, supra note 229, at 10. "[T] he court cannot reasonably conclude that the defendants were unjustly enriched when [the executives] received compensation for providing services to [to the company] pursuant to a contractual agreement approved by the [company's] board." Highland Legacy Ltd. v. Singer, No. Civ. A. 1566-N, 2006 WL 741939, at $\star 7$ n.73 (Del. Ch. Ct. Mar. 17, 2006).

27 Umpqua Holdings Order, supra note 230 , at $\star 3$ n.3 (citing Sommers v. Lewis, 2009 U.S. Dist. LEXIS 29776 , at $\star 8$ (D. Or. Apr. 8, 2009) ("Demand futility is determined under the law of the company's incorporating state-in this case, Oregon. This area of law is 'undeveloped' in Oregon, and courts often look to Delaware law for guidance.")).

$278 \quad$ Id. at 1.

$279 \quad$ Id.

280 Potter v. Hughes, 546 F.3d 1051, 1056 (9th Cir. 2008) (citing Smith v. Sperling, 354 U.S. 91, 96-97 (1957);

FED R CIV. P. 23.1.

281 Umpqua Holdings Order, supra note 230, at 7 (citing Potter, 546 F.3d at 1056).

$282 \quad$ Id.
} 
reasonable doubt is created that ... the challenged transaction was otherwise the product of a valid exercise of business judgment.' The two prongs of the Aronson test are disjunctive, meaning that if either part is satisfied, demand is excused."283

The Oregon Court first found that the plaintiffs' allegations that the Umpqua Board breached its fiduciary duties by approving the challenged executive compensation package and recommending it to the shareholders were unpersuasive. ${ }^{284}$ The Oregon Court held that the plaintiffs failed to meet the first prong of the Aronson test, because only one member of the Umpqua Board was also an executive officer and alleged to have received the compensation that plaintiffs were challenging and, therefore, the plaintiffs did not allege that demand was excused because a majority of Umpqua Holdings' directors lacked independence. ${ }^{285}$ The plaintiffs also cite to the Cincinnati Bell Holding that stated "the interest required to excuse the demand required is present because the board members face a substantial likelihood of liability in this derivative action."286 The Oregon Court found this argument to be unpersuasive, finding that the Cincinnati Bell case has recently been challenged on subject matter jurisdiction grounds and the plaintiffs' failure to disclose contrary authority in response to the court's specific inquiry in that case and also found that the plaintiffs reasoning was circular. ${ }^{287}$

The Oregon Court next analyzed whether the Umpqua Board's decision on executive compensation received protection under the business judgment rule. The business judgment rule is a "presumption that in making a business decision the directors of a corporation acted on an informed basis, in good faith and in the honest belief that the action taken was in the best interests of the company." ${ }^{288}$ The plaintiffs argue

283 Umpqua Holdings Order, supra note 230 , at *4 (citing In re J.P. Morgan Chase \& Co. Shareholder Litigation, 906 A.2d 808, 820 (Del. 2005)).

284 Umpqua Holdings Order, supra note 230 , at $\star 7$.

285 Id. at $\star 4$ ("A director will be considered unable to act objectively with respect to a presuit demand if he or she is interested in the outcome of the litigation or is otherwise not independent." The proper focus of the inquiry is "whether the director's decision is based on the corporate merits of the subject before the board, rather than extraneous considerations or influences." (quoting Beam $v$. Stewart, 845 A.2d 1040, 1048-49 (Del. 2004))).

286 Umpqua Holdings Order, supra note 230, at $\star 5$ (citing Cincinnati Bell Order, supra note 228).

287 Id. at $\star 5$ ("Under [p]laintiffs' reasoning, the fact that presuit demand is itself suggestive of impending liability is sufficient to create the type of self-interest that triggers the demand futility exception. This would permit every derivative action plaintiff to argue that demand is futile and need not be made because no board would be able to act objectively in evaluating a presuit demand.").

288 Umpqua Holdings Order, supra note 230, at $\star 5$ (quoting Unocal Corp. v. Mesa Petroleum Co., 493 A.2d 946, 954 (Del. 1985)) (A court "will not substitute its judgment for that of the board if 
that the adverse "say on pay" vote by a majority of shareholders constituted evidence that rebutted the presumption that the Umpqua Board's decision approving the executive compensation package and recommending it to shareholders reflected a valid business judgment. ${ }^{289}$

The Oregon Court rejected the plaintiffs' arguments as unpersuasive and held that "the board's actions do not directly defy or violate any Umpqua bylaw, any shareholder agreement, or any legally mandated disclosure or reporting requirement. Instead, Plaintiffs rely on a policy, pay for performance, that does not establish a binding standard for compensation and, notably, the board's statement regarding pay for performance was not made until after the compensation package had been approved." 290 The Oregon Court also found that "[g]iven that Delaware law, which the Dodd-Frank Act explicitly declined to alter, places authority to set executive compensation with corporate directors, not shareholders, this Court will not conclude that an adverse say on pay vote alone suffices to rebut the presumption of business judgment protection applicable to directors' compensation decisions." 291

\section{Comparison}

It is instructive to compare the three decisions in Cincinnati Bell, Beazer Homes, and Umpqua Holdings, because these are the first three decisions to be handed down in the crop of "say on pay" shareholder derivative lawsuits. The first point that needs to be made is that the decisions were made in different courts under different laws. The Cincinnati Bell case was heard in a federal court in Ohio applying Ohio law. The Beazer Homes case was heard in a state court in Georgia applying Delaware law. The Umpqua Holdings case was heard in a federal court in Oregon applying Oregon law. As stated above, in derivative claims brought under Federal law, the courts will apply the substantive law of the state of incorporation to determine whether demand is excused. ${ }^{292}$ This is important for companies to note, since a

the latter's decision can be attributed to any rational business purpose."); see also Crandon v. Shelk, 181 P.3d 773, 782 (Or. Ct. App. 2008).

289 Umpqua Holdings Complaint, supra note 94, 1132.

290 Umpqua Holdings Order, supra note 230, at $\star 8$. ("Plaintiffs' allegation that the board violated the pay for performance policy is not sufficient to overcome the business judgment presumption.") Id. at 16.

291 Umpqua Holdings Order, supra note 230, at $\star 8$ (quoting Beazer Homes Order, supra note 229, at 12).

292 See, e.g., Kamen v. Kemper Fin. Serv. Inc., 500 U.S. 90, 98 (1991); see also Burks v. Lasker, 441 U.S. 471, 478 (1979) (noting that corporations, as a rule, are creatures of state law). 
company may be incorporated in one state, but have its corporate headquarters in a different state. Beazer Homes is perfect example, being incorporated in Delaware and having its corporate headquarters in Georgia, where the lawsuit was filed.

The first distinction that needs to be made is that the shareholders in the Beazer Homes case were found to not have standing to bring a derivative claim. As stated above, the Georgia Court found that the alleged wrongful conduct cited by the plaintiffs occurred before they became shareholders. ${ }^{293}$ This is very important, because even if the Georgia Court found in favor of the plaintiffs substantively, procedure would not have allowed the case to continue. The shareholders in Cincinnati Bell and Umpqua Holdings did not face this obstacle.

The next distinction concerns the discussion of the companies' "pay for performance" policies. In the Cincinnati Bell case, the Ohio Court held that the allegations by the plaintiffs raised a plausible claim the executive compensation approved by the directors, in a time that the company's financial performance was declining, violated Cincinnati Bell's "pay for performance" policy and were not in the best interests of the shareholders. ${ }^{294}$ In the Beazer Homes case, the Georgia Court found that the plaintiffs did not allege that the challenged compensation package was inconsistent with executives' performance against predetermined financial goals and targets. ${ }^{295}$ It will be important for shareholders to explicitly state that the board of directors violated a company's "pay for performance" compensation policies when they approved the executive compensation structure.

The next distinction concerns the different pleading standards in the Cincinnati Bell, Beazer Homes, and Umpqua Holdings cases. In the Cincinnati Bell case, the Ohio Court stated "the business judgment rule imposes a burden of proof, not a burden of pleading." ${ }^{296}$ The Ohio Court went on to state "while a plaintiff must plead an exception to the business judgment rule, he is 'not required to plead the exception with

293 Beazer Homes Order, supra note 229, at 5.

294 Cincinnati Bell Order, supra note 228, at 5.

295 Beazer Homes Onder, supra note 229, at 9. It is interesting to note that the plaintiffs stated that the compensation package violated Beazer Homes' "pay for performance" executive compensation policy, but they failed to list it in their causes of action. See Beazer Homes Complaint, supra note 79, I 23 ("II]ncreasing 2010 CEO and top executive pay ... was unreasonably excessive and violated Beazer's pay-for-performance executive compensation policy.").

296 Cincinnati Bell Order, supra note 228, at 5 (quoting In re Nat'l Century Fin. Enters., Indiv. Litig., 504 F. Supp. 2d 287, 312 (S.D. Ohto 2007)). 
particularity." 297 In the Beazer Homes case, the Georgia Court stated that "demand excuse allegations 'must comply with stringent requirements of factual particularity ... [and] is not satisfied by conclusory statements or mere notice pleading." ${ }^{\prime 298}$ In the Umpqua Holdings case, the Oregon Court stated that demand excuse allegations must "state with particularity: any effort by the plaintiff to obtain the desired action from the directors or comparable authority and, if necessary, from the shareholders or members; and the reasons for not obtaining the action or not making the effort." ${ }^{299}$ This distinction is very important, since it will be state law that determines whether demand has been excused and the remaining shareholder derivative lawsuits have all been filed in different jurisdictions. ${ }^{300}$

The next distinction concerns the business judgment rule. In the Beazer Homes case, the Georgia Court held that the Dodd-Frank Act "expressly preserved the pre-existing fiduciary duty framework concerning executive compensation decisions" and concluded that an adverse say on pay vote alone did not rebut the presumption of business judgment protection applicable to directors' compensation decisions. ${ }^{301}$ In the Cincinnati Bell case, the Ohio Court held that the Cincinnati Board's decisions to approve the compensation in light of the financial standing of the company and the negative shareholder vote on the compensation created doubt that the challenged transactions were the result of a valid business judgment. ${ }^{302}$ In the Umpqua Holdings case, Oregon Court held that the Umpqua Board's actions did not violate any Umpqua bylaw, any shareholder agreement, or any legally mandated disclosure or reporting requirement and also found that Umpqua Holding's "pay for performance" policy did not establish a binding standard for compensation. ${ }^{303}$

297 Id. (quoting In re Tower Air, Inc, 416 F.3d 229, 236 (3rd Cir. 2005)).

298 Beazer Homes Order, supra note 229, at *4 (quoting Brehm v. Eisner, 746 A.2d 244, 254 (Del. 2000)); see also Brehm, 746 A.2d at 255 ("Plaintiffs are entitled to all reasonable factual inferences that logically flow from the particularized facts alleged, [although] conclusory allegations are not considered as expressly pleaded facts or factual inferences.").

299 Umpqua Holdings Order, supra note 230, at «3 (quoting FED R. CIV. P. 23.1(b)(3)).

300 The Jacobs Engineering case was filed in state court in California, the Umpqua Holdings case was filed in federal court in Oregon, the Hercules Offshore case was filed in state court in Texas, the Janus Capital case was filed in federal court in Colorado, and the Dex One case was filed in federal court in North Carolina.

301 Beazer Homes Order, supra note 229, at 6-7.

302 Cincinnati Bell Order, supra note 228 , at 9.

303 Umpqua Holdings Order, supra note 230 , at 14. 
Even though the Georgia Court ruled against the plaintiffs in the Beazer Homes case, the use of the language that an adverse "say on pay" vote alone does not rebut the presumption of business judgment rule protection leaves open the possibility that if the plaintiffs can submit additional evidence in combination with a negative "say on pay" vote, the outcome may be different. This is a critical distinction from the Ohio Court's reasoning in the Cincinnati Bell case, which found that the negative "say on pay" vote on executive compensation was enough to rebut the presumption of business judgment rule protection.

Another distinction is that in the Cincinnati Bell case, under Ohio law, demand was presumptively futile where the directors were adversely interested or involved in the transactions attacked. ${ }^{304}$ Under Ohio law, demand futility may also be established by suing all of the directors. ${ }^{305}$ In the Beazer Homes case, under Delaware law, to properly plead excused demand, plaintiffs had to raise a reasonable doubt that the challenged board decision was a valid exercise of business judgment or show that the directors faced a substantial likelihood of personal liability. ${ }^{306}$ In the Beazer Homes case, the Georgia Court also held that because the "say on pay" vote had not yet been held when the executive compensation structure was approved, the Beazer Board could not have considered the results of the vote in making their decision. ${ }^{307}$ I will directly address this concern of shareholders using hindsight when voting on executive compensation structures when discussing my proposals for amending the Dodd-Frank Act later in this article. ${ }^{308}$

It is also interesting to note that that the Cincinnati Bell Order was recently "called into question in light of the court's apparent lack of subject matter jurisdiction." ${ }^{309}$ However, even in light of this challenge, Cincinnati Bell approved a settlement in the case. According to Phillip R. Cox, Chairman of the Cincinnati Board, the settlement included "features which will clarify the Company's executive compensation policies and which will more clearly communicate these policies to our shareholders.

$304 \quad$ See id.

305 Carlson v. Rabkin, 789 N.E.2d 1122, 1128 (Ohio Ct. App. 2003) ("Examples of when demand would be excused as futile include when all directors are named as wrongdoers and defendants in a suit."); Drage v. Brunner, 694 N.E.2d 479, 483 (1997) ("when all directors are named as wrongdoers/defendants in a suit, futility may exist.").

306 See Beazer Homes Order, supra note 229 at 4.

307 Beazer Homes Order, supra note 229, at 10.

308 See infra Section V(A).

309 See Order Granting Defendants' Motion to Strike Phaintiffs' Amended Complaint and Notice of Voluntary Dismissal, NECA-IBEW Pension Fund v. Cox, No. 11-cv-451 (S.D. Ohio Dec. 21, 2011). 
Importantly, the changes represented by this agreement should better assist our shareholders' understanding of how these policies are applied to covered employees." ${ }^{310}$ Even though the ruling in the Cincinnati Bell case was challenged, because the case was settled on terms favorable to shareholders, plaintiffs will view this as a reason to continuing bringing shareholder derivative suits based upon negative "say on pay" votes on executive compensation.

From looking at the three Orders, it is clear that courts are split on whether shareholder derivative lawsuits based upon a negative "say on pay" vote on executive compensation are viable. It is also important to note that in the Beazer Homes and Umpqua Holdings cases, a state court in Georgia and federal court in Oregon were interpreting Delaware law. This will be a reoccurring theme, since many corporations are incorporated in Delaware, but have their corporate headquarters in a different state. Also, many courts look to Delaware law as a guide in cases concerning corporate law. ${ }^{311}$ A Delaware court may come to a different conclusion.

\section{SUGGESTIONS FOR COMPANIES}

With shareholders bringing derivative claims based on negative "say on pay" votes, companies can mitigate some of the risk by re-writing their pay for performance policies and also by responding actively to a negative "say on pay" vote on executive compensation.

Agreement Reached in Cincinnati Bell "Say on Pay" Lawsuit, CINCINNATI BeLL, INC. (Dec. 20, 2011), http://investor.cincinnatibell.com/phoenix.zhtml? $c=111332 \& \mathrm{p}=$ irol-newsArticle\&ID = 1641587\&highlight $=$.

311 See, e.g., Mullen v. Acad. Life Ins. Co., 705 F.2d 971, 974 n.3 (8th Cir. 1983) (per curiam) ("Courts of other states commonly look to Delaware law ... for aid in fashioning rules of corporate law."); Sommers v. Lewis, 641 F. Supp. 2d 1151, 1156 (D. Or. 2009) ("Oregon law is undeveloped in [the area of corporate law], so the parties look to Delaware law.");Wieboldt Stores, Inc. v. Schottenstein, 94 B.R. 488, 509 n.29 (N.D. Ill. 1988) ("Illinois courts have often looked to Delaware law for guidance in deciding previously undecided corporate law issues."); Dixon v. Ladish Co., 785 F. Supp. 2d 746, 754 (E.D. Wis. 2011) ("Delaware law can serve as a guide to corporate law issues in Wisconsin."); McMinn v. MBF Operating Acquisition Corp., 142 N.M. 160, 173 (N.M. 2007) (The Supreme Court of New Mexico "find[s] the Delaware approach instructive, based upon its reasoning and the experience of its courts in matters of corporate law."); Detwiler v. Offenbecher, 728 F. Supp. 103, 147 n.17 (S.D.N.Y. 1989) ("Michigan courts look to Delaware law as a guide for adjudicating matters involving corporate law."). 


\section{A. Re-Writing "Pay for Performance" Policies}

As stated earlier in this article, according to some financial experts, shareholders and institutional investors consider "pay for performance" as an integral aspect of executive compensation. ${ }^{312}$ During the 2011 Proxy Season, of the 340 recommendations by ISS to vote negatively on the proposed executive compensation, 177 , or about $52 \%$, of the negative ISS recommendations were based upon a company's "pay for performance" misalignment. ${ }^{313}$

When determining "pay for performance" alignment, ISS uses both a quantitative and qualitative method. ${ }^{314}$ First, ISS screens companies to identify the level of alignment between pay and performance over a sustained period; if a company shows unsatisfactory alignment, then they use a second-stage qualitative analysis to arrive at a final recommendation. ${ }^{315}$ During the quantitative analysis, ISS compares the "company's total shareholder return rank within a peer group, as measured over one-year and three-year periods, and the multiple of the CEO's total pay relative to the peer group median."316 During the qualitative analysis, ISS examines multiple factors to determine how various pay elements may work to encourage or to undermine long-term value creation and alignment with shareholder interests. ${ }^{317}$

Commentators have opined that "an effective approach to setting appropriate goals is to use probability analysis to determine the likelihood of attaining different levels of performance. ${ }^{318}$ Research has shown that consistently achieving goals set in this manner is associated with superior returns to shareholders. ${ }^{319}$ The analysis is based on rigorous analysis of

3122011 ISS Report, supra note 172, at 9.

313 Id. at 5.

$314 \quad$ Id. at 9.

315 Martin Rosenbaum, ISS Policy Updates Shed Light on Pay-for-Pefformance Analysis, ON SECURITIES (Nov. 20, 2011), http://www.onsecurities.com/2011/11/20/iss-policy-updates-shed-lighton-payforperformance-analysis.

316 Id. ("The peer group is generally comprised of 14 to 24 companies selected based on size and industry group.").

317 Id. These factors may include "the ratio of performance- to time-based equity awards;" "the ratio of performance-based compensation to overall compensation;" "the completeness of disclosure and rigor of performance goals;" and "any other factors deemed relevant" Id.

318 Eric Marquadt \& Matt Arnold, Setting Pefformance Goals in the New Disclosure Environment, BOARDROOM IQ (Sept. 9, 2011) http://www.boardroomiq.com/index.php/leadership/category/ chro_compensation_committee/setting_performance_goals_in_the_new_disclosure_environment.

$31 \overline{9} \quad$ Id. 
historical and expected performance data for the company and its peers. ${ }^{320}$ Because the analysis considers data from peer companies, it can help directors to set performance goals that are both competitive and realistic. ${ }^{321}$ The experts warn though that this analysis is not a substitute for business judgment; instead they are a foundation that directors can use to make sound goal-setting decisions. ${ }^{322}$

Companies need to "pay special attention to the rationale for compensation decisions where the company has underperformed its designated peers or the industry, even as executive compensation has increased. Even if not required as part of determining performance under the company's executive compensation plans, the compensation committee should review the company's one-, three- and five-year performance and total compensation relative to these groups. ${ }^{3323}$ Companies should also be aware of the "programs and or recommendations about pay decisions that may not conform to current trends in executive compensation, even where the deviations may be justified." 324

A valuable guide for setting "pay for performance" policies is the Financial Stability Board's ${ }^{325}$ Principles for Sound Compensation Practices. ${ }^{326}$ The FSB implementation standards were aimed at aligning compensation with long-term value creation. ${ }^{327}$ The elements include:

(i) avoiding multi-year guaranteed bonuses; (ii) requiring a significant portion of variable compensation to be deferred, tied to performance and subject to appropriate clawback and to be vested in the form of stock or stock-like instruments, as long as these create incentives aligned with long-term value creation and the

320
321
322
323

Id.

Id.

Id.

Edward F. Greene, Say-on-Pay and the Business Judgment Rule, THE HARVARD LAW SCHOOL Forum ON CORPorate GoVernance and Financial Regulation (Nov. 26, 2011), http://blogs.law.harvard.edu/corpgov/2011/11/26/say-on-pay-and-the-business-judgment-rule/.

$324 \quad$ Id.

325 The Financial Stability Board ("FSB") was established to "address vulnerabilities and to develop and implement strong regulatory, supervisory and other policies in the interest of financial stability." FINANCIAL STABLITY BOARD, http://www.financialstabilityboard.org (last visited Jan. 10, 2012).

326 FSB Principles for Sound Compensation Practices, FINANCLAL STABILITY BOARD (Sept. 25, 2009), http://www.financialstabilityboard.org/publications/__090925c.pdf.

327 Leaders' Statement: The Pittsburgh Summit Sept 24-25, 2009, G-20, available at http://www.treasury.gov/resource-center/internationa/g7-g20/Documents/pittsburgh_summit_leaders_ statement_250909.pdf (last visited Aug, 15, 2012). 
time horizon of risk; (iii) ensuring that compensation for senior executives and other employees having a material impact on the firm's risk exposure align with performance and risk; (iv) making firms' compensation policies and structures transparent through disclosure requirements; (v) limiting variable compensation as a percentage of total net revenues when it is inconsistent with the maintenance of a sound capital base; and (vi) ensuring that compensation committees overseeing compensation policies are able to act independently. ${ }^{328}$

"Pay for performance" has become a hot topic in recent years in the corporate arena and companies should avoid making broad policy assertions and fail to appropriately address the nuanced explanations of how the pay for performance policy will be applied in both good and bad economic times. ${ }^{329}$ Many proxy statements also suffer from not being user-friendly, because the drafting of the report focuses on "ticking the boxes" and complying with the detailed regulations that apply to proxy statements. ${ }^{330}$ Companies must realize the importance of the language they use in their policies when linking executive compensation to company performance and disclosures "should be drafted carefully to ensure that the disclosure adequately and accurately reflects the actual compensation decisions made with respect to each aspect of an executive's compensation. ${ }^{\text {"331 }}$

\section{B. Responding to a Negative "Say on Pay" Vote}

If a company receives a negative "say on pay" vote, it is important for its board of directors to actively respond. According to a recent $\mathrm{PwC}$ study, $72 \%$ of U.S. companies would be willing to reconsider executive compensation if the company received a negative "say on pay" vote on executive compensation. ${ }^{332}$

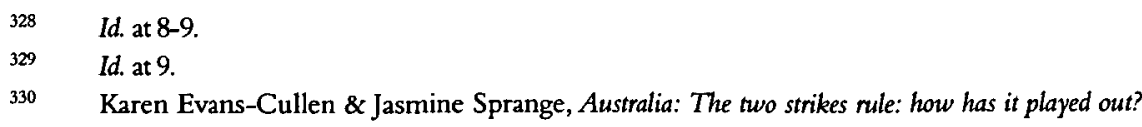

MONDAQ (Jan. 18, 2012), http://www.mondaq.com/australia/x/158780/Directors + Officers + Executives +Shareholders/The + two + strikes + rule + how + has + it + played +out.

331 Amy M. Shepherd, Say-On-Pay and the Cincinnati Bell and Beazer Homes Decisions, BAKER HOSTETLER (Oct. 12, 2011), http//www.bakerlaw.com/alerts/say-on-pay-and-the-icincinnati-bell-andbeazer-homes-decisions-10-12-2011.

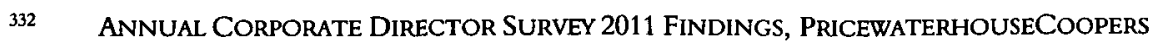
4, http:/www.pwc.com/en_US/us/corporate-governance/assets/annual-corporate-director-survey- 
Companies may look at the language used by the Georgia Court in the Beazer Homes Order that stated "the say on pay vote did not require that challenged pay be rescinded and does not support a reasoned inference that any alleged failure to do so was not a valid business judgment" and that there was "nothing to suggest that the Beazer Board's failure to rescind the challenged pay rebuts the business judgment rule or suffices to excuse demand." ${ }^{333}$ However, this language should not persuade a company to not actively respond to a negative "say on pay" vote.

If a company receives a negative "say on pay" vote, the board of directors should consider whether changes should be made to the executive compensation structure. The board of directors should also make sure any changes they make to the executive compensation structure are made public in a timely manner, especially to the shareholders. "While companies should not make substantive compensation decisions that they do not believe are in the best interests of shareholders merely in the hopes of increasing support for their say on pay proposals, changes may be appropriate where a company feels upon reflection that its compensation arrangements could be improved based on feedback from its shareholders. ${ }^{\text {"334 }}$ Even if a company decides not to take action after a negative "say on pay" vote, the Board should include a reasoned analysis explaining why the executive compensation package remains appropriate. ${ }^{335}$

In a November 2011 speech, Mary L. Schapiro, Chairman of the Securities and Exchange Commission ("SEC"), discussed how companies that receive a negative "say on pay" vote on executive compensation should respond. ${ }^{336}$ She stated that companies should ask themselves very tough questions concerning their execute compensation practices. The questions would include: "Should executive compensation policies be altered in response to the vote?" "[h]as the board's executive compensation philosophy been clearly articulated to shareholders?" and

\footnotetext{
2011.pdf (last visited April 15, 2012) [hereinafter PWC 2011 DIRECTOR SURVEY].

333 Beazer Homes Order, supra note 229, at 13.

334 Jeremy L. Goldstein, How to Win the Say on Pay Vote, THE HaRvard LAw SCHOOL FORUM on Corporate Governance and Financial Regulation (Dec. 1, 2011, 9:31 AM), http://blogs.law.harvard.edu/corpgov/2011/12/01/how-to-win-the-say-on-pay-vote/.

335 Id.

336 Mary L. Shapiro, Speech by SEC Chaiman: Remarkes to TheCoporateCounsel.Net "Say-on-Pay Workshop Conference," U.S. SECuRITIES AND EXCHANGE COMMISSION (Nov. 2, 2011), http//www.sec.gov/news/speech/2011/spch110211 mls.htm.
} 
"[s]ubstantively, what should the Board consider changing about its compensation plans?"337

As an example, Helix Energy systems, a company that received a negative "say on pay" vote in 2011 , stated that it would add performance metrics to its 2011 cash bonus program for executive compensation. ${ }^{338}$ It is unclear whether this type of action will convince shareholders to withdraw the current derivative lawsuits or stop them from filing future derivative lawsuits, but even if shareholders file suit based upon a negative "say on pay" vote on executive compensation, actions taken to respond positively to a negative "say on pay" vote could be looked on favorably by the court. The amendment to the Dodd-Frank Act proposed later in this article will force companies to respond to a negative "say on pay" vote and inform shareholders whether any action has been taken, or in the alternative, why action has not been taken. ${ }^{339}$

\section{AMENDING THE DODD-FRANK ACT}

This article has discussed, in detail, multiple derivative lawsuits brought by shareholders after a negative "say on pay" vote on executive compensation. This section of the article discusses amending the DoddFrank Act to give shareholders greater influence over the decisions made by a company and its board of directors concerning executive compensation. The amendment would provide that a second successive negative "say on pay" vote $(50 \%$ or more of shareholder votes cast against the proposed executive compensation package) on executive compensation would prompt a vote on a "spill" resolution and, if that resolution passes, all directors, except for the managing director, must stand for re-election at a special "spill" meeting within 90 days of annual shareholder meeting where the "spill" resolution passed.

\section{A. Implementing a "Two-Strikes" "Say on Pay" Re-Election Policy for Directors}

\section{Language of the Proposed Amendment}

This article proposes an amendment to the Dodd-Frank Act that would provide that a second successive negative "say on pay" vote $(50 \%$ or

\footnotetext{
$337 \quad$ Id.

$338 \quad 2011$ ISS Report, supra note 172, at 19.

339 See infra Section V(A)(2).
} 
more of shareholder votes cast against the proposed executive compensation package) on executive compensation would prompt a vote on a "spill" resolution and, if that resolution passes, all directors, except for the managing director, must stand for re-election at a special "spill" meeting within 90 days of annual shareholder meeting where the "spill" resolution passed. The proposed amendment is based on a recently enacted Australian law which is referred to as the "two-strikes" rule. ${ }^{340}$ This amendment would be codified as the new 15 U.S.C. $\$ 78 n-1$ (d). The amendment would be codified as:

(d) Two Successive Negative Shareholder Votes

(1) If a company receives a negative shareholder vote $(50 \%$ or more of shareholder votes cast against the proposed executive compensation package) on the compensation of executives (referred to in subsection (a)), in the subsequent proxy statement, the company must explain any response taken to the negative shareholder vote or explain why they did not take any action and the company must also include provisions for a "spill" resolution at the following annual shareholder meeting;

(2) If a company receive receives a second successive negative shareholder vote $(50 \%$ or more of shareholder votes cast against the proposed executive compensation package) on the compensation of executives (referred to in subsection (a)), the shareholders will vote on the "spill" resolution and, if the resolution passes $(50 \%$ or more of shareholder votes cast in favor of the resolution), all directors, except the managing director, must stand for re-election:

(i) the "spill" meeting must be held within 90 days of the annual shareholder meeting where the "spill" resolution passed;

(ii) all of the company's directors who were directors of the company at the time of the second successive negative shareholder vote will cease to hold office immediately before the "spill" meeting;

(iii) shareholders that have continuously held at least 5 percent of the voting power of the company's securities entitled to be voted for at least three years may nominate directors to be voted on at the "spill" meeting;

(iv) resolutions to appoint persons to offices that will be 
vacated immediately before the end of the "spill" meeting must be put to the vote at the "spill" meeting;

(v) to ensure that a company has the minimum amount of directors required by law, the persons that will be appointed are those with the highest number of votes favouring their appointment, even if less than $50 \%$ of the votes cast were in favour of their appointment;

(v) if a director who ceased to hold office immediately before the "spill" meeting is appointed as director by resolution passed at the "spill" meeting, his or her term of office runs as if the cessation and appointment had not happened;

(vi) if the company does not hold the "spill" meeting within 90 days after the annual shareholder meeting where the "spill" resolution was passed, each director will be personally fined $\$ 1000$ dollars per day until the meeting is held.

(3) Executive officers that hold any of the voting power of the company's securities to be voted will not be allowed to vote on the compensation of executives (referred to in subsection (a)) or on the "spill" resolution (referred to in subsection (d)(2)).

(4) Companies with less than $\$ 250,000,000$ in total assets are exempted from this Section.

\section{Interpretation of Proposed Amendment}

Under this proposed amendment, the first strike occurs when at least $50 \%$ of the eligible votes cast oppose the executive compensation structure. This triggers a duty by the company to explain any response (or non response) to the "say on pay" vote. Following the receipt of one strike, companies must include on the Proxy Statement for the next annual shareholder meeting a "spill" resolution. To the extent that $50 \%$ of the shareholder votes are cast against the executive compensation structure and the "spill" resolution passes, all directors except the managing director must stand for re-election. ${ }^{341}$

Shareholders that have continuously held at least 5 percent of the voting power of the company's securities entitled to be voted for at least three years may nominate directors to be voted upon at the "spill" meeting. If shareholders at the "spill" meeting don't appoint enough directors to ensure that the company keeps its required minimum number

341 See Explanatory Memorandum, Improving Accountability on Drrector and Executrve Remuneration Act, 2011, No. 42 (Austl.). 
of directors, ${ }^{342}$ vacancies are filled by those directors who received the highest number of votes even if they didn't receive enough votes to be formally elected. If a company receives a negative "say on pay" vote year after year, there will be no requirement to hold a "spill" vote if one was held at the previous year's annual shareholder meeting. Also, because a company will not know whether they will receive a second successive negative "say on pay" vote at the annual shareholder meeting, the notice of meeting and proxy forms will have to make provision for voting on a "spill" resolution. Executive officers who hold shares of common stock are also prohibited from voting on their own compensation awards and companies that have less than $\$ 250,000,000$ in total assets will not be subject to this regulation.

\section{B. Cost-Benefit Analysis}

It is important to provide a comprehensive study on how this proposed amendment would affect companies and their shareholders. ${ }^{343}$ It is imperative to look at both economic and non-economic factors and try to foresee both positive and negative impact the legislation will have.

It is instructive to look at the regulation impact statement on Australia's "two-strikes" rule, since that is what the proposed Amendment to the Dodd-Frank Act in this article is based. The Productivity Commission ("PC"), who prepared the regulation impact statement for the Australian Treasury, reported that the "two-strikes" rule was the best option, as compared to both a binding and non-binding shareholder vote on executive compensation. 344 The report found that a "two-strikes" policy would address the problems associated with executive compensation and "provide an additional level of accountability for directors and increased transparency for shareholders." ${ }^{345}$ The PC found that where a company "faces significant 'no' votes over two consecutive years, and the company has not adequately responded to concerns raised by shareholders the previous year, it is appropriate for the boards of such companies to be subject to greater scrutiny and accountability through the

\footnotetext{
342 The minimum number of directors is based on state law and/or a company's articles of incorporation.

343 Under President Clinton's Executive Order 12866 and the Unfunded Mandates Reform Act of 1995, federal agencies are required to analyze the costs, benefits, and other effects of proposed regulations. Exec. Order No. 12,866, 3 C.F.R. 638 (1993-2000), reprinted in 5 U.S.C. $\$ 601$ (1994), and in 2 U.S.C. $\$ 1501$ (2011).

344 See Explanatory Memorandum, supra note 341.

345

Id.
} 
re-election process" and that the "two-strikes" rule "strengthens the nonbinding vote and maintains the fundamental principle underlying [the] corporate governance framework that directors are responsible for, and accountable to, shareholders on all aspects of the management of the company, including the amount and composition of executive remuneration." 346

Australian directors have also backed the "two-strikes" rule implemented in Australia. Many company directors believe the "two strikes" rule has re-empowered boards in discussions with management on the issue of executive compensation. ${ }^{347}$ Insurance Australia Group ("IAG") director Yasmin Allen stated "while she initially believed the two strikes reforms were too heavy handed, she now thought the changes had improved dialogue in boardrooms on executive pay.",348 Respected fund manager John Sevior has also backed the "two-strikes" rule by stating that " $[t]$ o hear widespread criticism of the two-strikes rule from high-profile sections of the directors' club means it is a step in the right direction." 349

Data compiled by Investor Weekly, a national online news and information service for Australian investors, shows that about $9 \%$ of ASX $200^{350}$ companies received a negative vote against their remuneration report. That figure is down from a three-year average of about $14 \%{ }^{351}$ There is empirical evidence that "some boards [] made extra effort to communicate their position on executive pay matters to superannuation funds, fund managers, proxy advisers and retail investor groups."

Even with mostly positive feedback for the "two strikes" rule in Australia, American companies will be wary of any new regulation concerning executive compensation. Companies will argue that the proposed amendment would have a large effect on the economy and entire industries would be impacted. This argument is unpersuasive. As noted above, as of June 2011, shareholders returned negative "say on pay"

\footnotetext{
$346 \quad$ Id.

347 Damon Kitney, Directors Back Tub-Strike Rule at 50pc, (Dec. 19, 2011, 12:00AM), $\mathrm{http} / /$ www.theaustralian.com.au/business/companies/directors-back-two-strike-rule-at-50pc/story-fn91v9q31226225266729.

$348 \quad$ Id.

349 James Frost, Sevior Backs Executive Two-Strikes Pay Rule, THE AUSTRALIAN (Oct. 29, 2011), http://www theaustralian.com.au/business/companies/sevior-backs-executive-two-strikes-payrule/story-fn91v9q3-1226179957662.

350 Australia's 200 largest stocks by market capitalization.

351 Tony Featherstone, Two Strikes Round One, MORNINGSTAR.COM, http://www.morningstar.com.au/funds/article/two-strikes/4311 (last visited Mar. 2, 2012).

$352 \quad$ Id.
} 
votes at only 45 , or $1.9 \%$, of companies. ${ }^{353}$ This number reflects that over $98 \%$ of "say on pay" votes were positive. The empirical evidence suggests that "say on pay" votes are negative only in the most egregious of circumstances and for the "two strikes" regulation to apply, there would have to be two successive negative "say on pay" votes. The proposed amendment also exempts companies with less than $\$ 250,000,000$ in total assets. ${ }^{354}$

Companies will argue that the legislature and the courts have given board of directors' wide discretion in the area of executive compensation. Courts have stated that directors, rather than shareholders, manage the business and affairs of the corporation. ${ }^{355}$ They will argue that directors' authority to manage the affairs of a company includes "wide discretion" to set executive compensation. ${ }^{356}$ They will also argue that "informed decisions regarding employee compensation by independent board are usually entitled to business judgment rule protection." ${ }^{357}$ Historically, as discussed above, directors' have great latitude when it comes to decisions on executive pay.

However, in recent years, courts have chipped away at that "wide discretion" given to directors. In a recent decision from the U.S. District Court for the Southern District of New York, the District Court held that directors and executive compensation consultants "have a skewed focus when it comes to executive compensation, concentrating on what they perceive is necessary to attract and keep 'talent' (however defined), and more generally favoring ever larger compensation packages, while rarely taking account of limits that a reasonable shareholder might place on such expenditures." ${ }^{358}$ Judge Richard A. Posner, dissenting in a $7^{\text {th }}$ Circuit Court of Appeals case, stated that "executive compensation in large publicly traded firms often is excessive because of the feeble incentives of boards of directors to police compensation." 359 Courts have also found that there is an outer limit to the directors' discretion, at which point a decision of the directors on executive compensation is so

\footnotetext{
353 See Equilar Report, supra note 41 at 1.

354 This provision makes the regulation fair for smaller companies, because smaller companies with lower levels of assets generally do not have the ability to award excessive executive compensation packages.

355 Aronson v. Lewis, 473 A.2d 805, 811 (Del. 1984).

356 Brehm v. Eisner, 746 A.2d 244, 262 n.56 (Del. 2000); Haber v. Bell, 465 A.2d 353, 359

(Del. Ch. 1983) (explaining that "generally directors have the sole authority to determine compensation levels").

357 Prod. Res. Grp., LLC v. NCT Grp., Inc, 863 A.2d 772, 799 (Del. Ch. 2004).

358 SEC v. Bank of Am, 09 Civ. 6829, 2010 U.S. Dist. LEXIS 15460 at $\star 14$ (S.D.N.Y. Feb. 22, 2010).

359 Jones v. Harris, 537 F.3d 728, 730 (7th Cir. 2008) (Posner, J., dissenting).
} 
disproportionately large as to be unconscionable and constitute waste. ${ }^{360}$ These cases show that even though directors have wide discretion in setting executive compensation, it is not unlimited and may be challenged.

Implementation of a "two-strikes" regulation under the Dodd-Frank Act will not alter the principle that directors are responsible for managing a company's operations, including setting executive compensation. It will, however, provide an additional level of accountability for directors and also provide increased transparency for shareholders. ${ }^{361}$ During a parliamentary debate concerning Australia's "two-strikes" rule, Australian House Representative Gai Brodtmann stated that the legislation was "a step forward in ensuring that shareholders and Australians generally have faith in the accountability of directors and senior executives of Australian companies and, most importantly, in the fairness of their pay. It does this not by regulation but by an approach that respects the need for firms to operate freely in the market, at the same time giving shareholders the power they need to make sure that senior executives truly earn their pay." 362

This "two-strikes" regulation will still leave power with the board to set executive compensation, but the board will find itself subject to the equivalent of a vote of confidence. ${ }^{363}$ "The failure to obtain approval effectively amounts to a vote of 'no confidence' in the remuneration committee, is regarded as a significant blow to the board's authority and is typically widely reported."364 The threat of being removed by shareholders can also give directors the leverage to stand up to assertive managers. ${ }^{365}$ The disruptive effect of a board "spill" will also minimize the perception that high levels of executive compensation are the result of chummy negotiations between directors and executive officers. ${ }^{366}$

360 See Saxe v. Brady, 184 A.2d 602, 610 (Del. Ch. 1962); see also Grimes v. Donald, 673 A.2d 1207, 1215 (Del. 1996) (explaining that directors have discretion to set executive compensation levels "unless the facts show that such amounts, compared with the services to be received in exchange, constitute waste or could not otherwise be the product of a valid exercise of business judgment").

361 See Explanatory Memorandum, supra note 341.

362 Commonwealth of Australia, Parliamentary Debate, S. House of Representatives, No. 5, 2011 (statement of Rep. Brodtmann).

363 Jeremy Ryan Delman, Stnucturing Say-On-Pay: A Comparative Look at Global Variations in Shaneholder Voting on Executive Compensation, 2010 COLUM. BUS. L. REv. 583, 613 (2010).

364 Guido Ferrarini, Niamh Moloney, \& Maria Cristina Ungureanu, Understanding Directors Pay in Europe: $A$ Comparative and Empirical Analysis 17 (European Corporate Governance Institute Working Paper No. 126/2009, 2009), available at http://papers.ssrn.com/sol3/ papers.cfm?abstract_id $=1418463 \&$ rec $=1 \&$ srcabs $=1425469$.

365 Id.

$366 \quad I d$. 
Companies will also argue that an advisory "say on pay" vote is enough and that shareholders already have the power to remove directors if they believe they are not meeting expectations. However, this is easier said than done. Regarding the advisory "say on pay" vote argument, Richard Ferlauto, Director of Pension and Benefit Policy at American Federation of State, County and Municipal Employees ("AFSCME"), testified before Congress that "[a] large shareholder vote against a pay report is the yellow card warning to the company board. If this warning is not heeded and pay practices are not reformed and better aligned with performance, then shareholders have the opportunity to use the red card by replacing failed directors." 367

Regarding the removal of directors, the primary role of shareowners is to elect and remove directors, but there are major hurdles for shareholders to overcome. ${ }^{368}$ Lucian Bebchuk, Director of the Program on Corporate Governance at Harvard Law School, has written that "[s]hareholders' power to replace directors plays a critical role in the accepted view of the corporation" and that the "safety valve of potential ouster via ballot box - on which our corporate governance system is supposed to rely - has been all but shut off." ${ }^{369}$ Companies have argued that the board is in a better position to nominate qualified directors than shareholders are; however, the U.S. Supreme Court has stated that directors should not "attribute to investors a child-like simplicity.",370

367 Empowering Shareholders on Executive Compensation: Hearing on H.R. 1257 Before the H. Comm. on Financial Servs., 110th Cong. (2007) (testimony of Richard Ferlauto, Director of Pension and Benefit Policy, American Federation of State, County and Municipal Employees).

368 INVESTORS' WORKING GROUP, U.S. FINANCIAL REGULATORY REFORM: THE INVESTORS' PERSPECTIVE 27 (2009), http:/www.cii.org/UserFiles/file/ resource\%20center/investment\%20issues/Investors\%27\%20Working\%20Group\%20Report\%20\%28Jul y\%202009\%29.pdf.

369 Jeremy Ryan Delman, Survey: Structuring Say-On-Pay: A Comparative Look at Global Variations in Shareholder Voting on Executive Compensation, 2010 COLUM. BUS. L. REV. 583, 613 n.190 (2010) (citing LuCIAN BEBCHUK \& JeSSE FRIED, PAY WITHOUT PERFORMANCE: THE UNFulfilled PROMISE OF EXECUTIVE COMPENSATION 207-08 (2004)). Lucian Bebchuk \& Jesse Fried, PAY WITHOUT PERFORMANCE: THE UNFULFILlED PROMISE OF EXECUTIVE COMPENSATION 23 (2004). Professor Bebchuk has also stated "attempts to replace directors are extremely rare, even in firms that systematically under-perform over a long period of time. By and large, directors nominated by the company run unopposed and their election is thus guaranteed" and that " $[w]$ hether the nomination committee is controlled by the CEO or by independent directors, incentives to serve the interests of those making nominations are not necessarily identical with incentives to maximize shareholder value." Lucian Bebchuk, Shareholder Access to the Ballot (Regulatory Policy Program Working Paper RPP-2003-16).

370 Basic, Inc. v. Levinson, 485 US 224, 234 (1988) (quoting Flamm v. Eberstadt, 814 F.2d 1169, 1175 (7th Cir. 1987)). 
Also, given that the shareholders stake in the company and money are on the line, they naturally would have an incentive to make the decision that would best serve their interests, i.e. nominating directors that will increase the profitability of the company. ${ }^{371}$

The SEC recently tried to make it easier for shareholders to include shareholder nominees for director on company proxy materials. This regulation would require companies to "include shareholder nominees for director in the company's proxy materials, if the shareholder meets certain conditions, and if the shareholders are not otherwise prohibited - either by applicable state or foreign law or a company's governing documents from nominating a candidate for election as a director."372 However, in July 2011, the U.S. Court of Appeals for the District of Columbia invalidated the regulation and the SEC has decided not to appeal the ruling. ${ }^{373}$

By amending the Dodd-Frank Act, it will also cut down on costs associated with litigation. If shareholders can use the "say on pay" vote to affect the directors' decision concerning executive compensation, they will not have to file a derivative shareholder suit. This would save both the company and shareholders from paying court costs and lawyers' fees, along with costs associated with litigation (discovery costs, labor costs, etc.). The proposed amendment to the Dodd-Frank Act will solve the problems shareholders are trying to resolve with litigation, namely, whether directors will have to actively respond to their "say on pay" vote in executive compensation.

The vote on the "spill" resolution after two successive negative "say on pay" votes will also moot the argument made by the Georgia Court in the Beazer Homes case that stated "because the say on pay vote had not yet been held when the challenged decisions to approve the pay at issue and recommend that shareholders vote to approve it were made, the Beazer Board could not have considered the results of the vote in making those decisions. ${ }^{374}$ The directors will have a year to either change the executive compensation structure for the company or, in the alternative,

\footnotetext{
371 Bebchuk, supra note 369, at 15.

372 See US SECURTIIES AND EXCHANGE COMMISSION, SEC Adopts New Measures to Facilitate Director Nominations by Shareholders (Aug. 25, 2010), http://www.sec.gov/news/press/2010/2010155.htm.

373 See Business Roundtable v. SEC, 647 F.3d 1144 (D.C. Cir. 2011); see also Jessica Holzer, No Appeal on SEC Proxy Rule, WALL ST. J. (Sept. 8, 2011), http://online.wsj.com/ article/SB10001424053111904900904576555253963782370.html? mod=googlenews_wsj.

374 Beazer Homes Order, supra note 229, at 11.
} 
convince the shareholders to vote in favor of the executive compensation structure at the next annual shareholder meeting.

\section{Policy Considerations}

There are many policy considerations when amending a regulation or statute. This is even truer when looking at a controversial law, such as the Dodd-Frank Act. Robert Monks, a veteran corporate governance activist who founded ISS in 1985, stated that "[s]ay-on-pay is at best a diversion and at worst a deception" and "[y]ou only have the appearance of reform, and it's a cruel hoax." 375

There is a growing concern regarding excessive executive compensation packages. The current median pay of CEOs sits at $\$ 11.4$ million, according to the The American Federation of Labor ad Congress of Industrial Organizations ("AFL-CIO"). ${ }^{376}$ According to a study by the Institute for Policy Studies ("IPS"), 377 "two years into the worst economic crisis since the Great Depression, executive pay - after adjusting for inflation - is still running at double the 1990s CEO pay average, quadruple the 1980s average, and eight times the average executive pay in the mid-20th century. ${ }^{378}$ According to a Global Market Insite, Inc. ("GMI") ${ }^{379}$ survey, executive compensation has risen $36.5 \%$ in just the last year. ${ }^{380}$ A recent PwC study found that in $2010,44 \%$ of corporate directors believed that U.S. companies are having trouble controlling the size of CEO compensation. ${ }^{381}$

This is concerning, especially because the IPS study also reported that "American workers, by contrast, are taking home less in real weekly wages

375 John Helyar, Investor 'Say on Pay' Is a Bust, BusinessweEK.COM (June 16, 2011), http:/www.businessweek.com/magazine/content/11_26/b4234023747122.htm.

376 Trends in CEO Pay, AFL-CIO, http:/www.aflcio.org/Corporate-Watch/CEO-Pay-and-the99/Trends-in-CEO-Pay (last visited Mar. 3, 2012); see also Dale Wannen, How Shareholders are Battling Excessive Executive Compensation, TRIPLE PUNDIT (June 30, 2011), http://www.triplepundit.com/ 2011/06/staying-engaged-bosss-paycheck/.

37 IPS is a progressive think tank based in Washington, DC.

378 Sarah Anderson, Chuck Collins, Sam Pizzigatı \& Kevin Shih, CEO Pay and the Great Recession, INSTITUTE FOR POLICY STUDIES (Sept. 1, 2010), available at http://www.fpif.org/ files/2433/EE-2010-web.pdf

379 GMI is a market research firm headquartered in Bellevue, Washington

380 Greg Ruel, Michelle Lamb \& Paul Hodgson, GMI's 2011 CEO Pay Survey, GMI RATINGS (Dec. 2011), 61/GMI_CEOPay2011_122011.pdf. http//origin.library.constantcontact.com/download/get/file/1102561686275-

381 PuC 2011 DiRECTORSURVEY, supra note 332, at 25. 
than they took home in the 1970s. ${ }^{382}$ The AFL-CIO found that in 1980, CEO pay equaled 42 times the average blue collar worker's pay and by 2010, CEO pay had grown to 343 times workers' median pay. ${ }^{383}$ Even more concerning is the report's finding that "CEOs at the 50 major firms that have laid off the most workers since the onset of the economic crisis took home nearly $\$ 12$ million each on average in 2009,42 percent more than the average compensation that went to S\&P 500 CEOs. ${ }^{\text {"384 }}$ Robert Reischauer, head of the Urban Institute ${ }^{385}$ and former director of the Congressional Budget Office, stated that the issue of executive compensation can also be more symbolic than substantive. ${ }^{386}$ Reischauer states that "[executive compensation] is an important symbol [and that] in other countries, CEOs are not making a thousand times more than factory workers. ${ }^{387}$

\section{Comparative Study}

In July 2011, a group of European scholars conducted an experiment to study the consequences of "different shareholder voting right regimes on CEOs' investment incentives, shareholders' voting behavior, executive compensation, and firm profit." ${ }^{388}$ The study considered three different types of shareholder voting right regimes and compared them to a system in which shareholders had no "say on pay" vote on executive compensation. ${ }^{389}$

The experiment reported that "advisory shareholder voting rights do not reduce compensation. We even find that nonenforceable voting rights have an adverse effect on executive pay. In fact, they seem to motivate CEOs to demand higher bonuses compared to the scenario where shareholders have no voting rights. The latter effect is small but

\footnotetext{
382 Id. at 4

383 For calculations, see AFL-CIO, Executive Pay Watch, www.paywatch.org (last visited Mar. 3,

2012).

384 Anderson, et al., supra note 378 , at 5.

385 The Urban Institute is a non-partisan think-tank based in Washington, DC.

386 Albert R. Hunt, Corporate Chiefs May Come to Rue Fat Paydays, BlOOMBERG (Feb. 19, 2007), $\mathrm{http} / / \mathrm{www}$.bloomberg.com/apps/news?pid = newsarchive\&refer $=$ columnist_hunt\&sid $=$ arth8j9wbrcc.

$387 \quad$ Id.

388 Robert F. Göx, Frédéric Imhof, \& Alexis H. Kunz, Say on Pay Design and its Repercussion on CEO Investment Incentives, Compensation and Firm Profit (Apr. 13, 2010), available at http://ssrn.com/abstract $=1588682$.

389 Id.
} 
statistically significant." ${ }^{390}$ The report also stated unconditional binding "say on pay" votes can "distort CEO investment incentives which results in reduced firm profits;" however, "[ $t$ ] avoided by conditionally binding voting rights." ${ }^{391}$ The "two-strikes" regulation proposed in this article strikes a balance between the interests of shareholders and a desire of business to give appropriate incentives to their executives to generate growth.

It is also instructive to look at countries that have mandated binding shareholder "say on pay" votes on executive compensation. As noted earlier in this article, the Netherlands (2004), Sweden (2007), Denmark (2007), and Norway (2007) have enacted regulations requiring companies to submit executive remuneration to a binding vote. ${ }^{392}$ The legislation in these countries requires a binding vote where shareholders approve the compensation policies of the company. The remuneration vote is on future policies rather than a retroactive look at policies implemented in the prior year and if shareholders vote against a new policy or changes to a previously implemented policy, the company can only rely upon past practices. ${ }^{393}$

In 2004, the Netherlands adopted the Tabaksblat Code, which made compliance with corporate governance principles (code of best practices) mandatory by law. ${ }^{394}$ Under the Tabaksblat Code, the vote covers pay policy only, not the remuneration report itself; this means "Dutch shareholders vote only on the principles that will be used to devise the following year's pay package. ${ }^{395}$ If shareholders vote down the new policy, the existing one remains in effect. ${ }^{396}$ In 2007, Sweden adopted a binding senior management remuneration policy which states that " $[t]$ he board is to present a proposal for the company's policy on remuneration and other terms of employment for senior management to the annual general meeting for its approval. ${ }^{397}$ In the Netherlands, it is also important to note that if a company does not change its pay policy, then it

\footnotetext{
$390 \quad I d$.

$391 \quad$ Id.

$392 \quad I d$

393 John Tuzyk \& Angela Scott, Say-On-Pay Shareholder Voting, BLAKES (June 16, 2009), http://www.blakes.com/english/view_disc.asp?ID $=3207$.

394 See Tabaksblat Code, available at http:/www.ecgi.org/codes/documents/cg_code_nl_en.pdf.

395 Delman, supra note 363, at 593 citing STEPHEN DEANE, WHAT INTERNATIONAL MARKETS SAY ON PAY: AN INVESTOR PERSPECTIVE 7 (Institutional Shareholder Servs. 2007).

396 Id.

397 Swedish Code of Corporate Governance 4.2 .2 (2007), available at http:/www.ecgi.org/codes/ documents/swedish_cg_070913_en.pdf.
} 
does not have to put it to a shareholder vote. ${ }^{398}$ However, Sweden, Norway, and Denmark all mandate binding shareholder votes to be annual, even when there has been no year-to-year change in principles. ${ }^{399}$

\section{ConClusion}

Shareholders are considered the "owners" of a corporation and therefore given rights at the expense of other corporation constituents. ${ }^{400}$ By allowing the shareholders a mechanism to affect executive compensation, it will allow them to be more involved in the management of the company. "It is appropriate that shareholders, who ultimately bear the risk associated with the performance of companies in which they hold equity, have an opportunity to thoroughly scrutinise remuneration packages." ${ }^{401}$

The issue of shareholders being able to control executive compensation will be part of the legal discussion for the foreseeable future. Paul Hodgson, senior research associate at GMI, said the "sharp rise in pay was out of line with the relatively modest improvement that companies typically achieved in profits or share price during $2010 .^{n 402}$ Under the proposed "two-strikes" regulation, by allowing shareholders a stronger voice on how executives are compensated, executive pay might one day be more in line with company performance.

398 Id.

$399 \quad$ Id.

400 See Karmel, supra note 217.

401 Commonwealth of Australia, Parliamentary Debate, S. House of Representatives, No. 5, 2011 (statement of Rep. Smyth).

402 Chris Isidore, CEO Pay Jumps 36.5\%, CNNMONEY.COM (Dec. 15, 2011, 1:49 PM), http://money.cnn.com/2011/12/15/news/companies/ceo_pay/index.htm. 
